\title{
Frumkvæði nemenda: Innlit í kennslustundir níu framhaldsskóla
}

\author{
Gerður G. Óskarsdóttir
}

\begin{abstract}
Um höfundinn $\quad$ About the author $\quad$ Heimildir
Frumkvæði og sköpun nemenda eru áherslupættir í íslenskum lögum og námskrá fyrir framhaldsskóla. Sömu áherslur má sjá í fjölbjóðlegri stefnumörkun í menntamálum. Gera má rád fyrir að pær byggist á umfjöllun fræðimanna í nánast heila öld um mikilvægi pess að nemendur hafi eitthvað að segja um framkvæmd náms og kennslu, í stað pess að vera fyrst og fremst viðtakendur upplýsinga. Markmið greinarinnar er að varpa ljósi á tækifæri framhaldsskólanemenda til frumkvæðis við úrlausn viðfangsefna sem kennari leggur fyrir í kennslustundum, nánar tiltekið umfang peirra og birtingarmynd. Byggt er á 130 vettvangslýsingum úr níu framhaldsskólum og viðtölum við 17 nemendahópa. Við greiningu gagna var stuðst við priggja prepa frumkvæðiskvarða: á fyrsta prepi eru ekki tækifæri til frumkvæðis, á öðru er möguleiki á eða ætlast til einhvers frumkvæðis, en á pví priðja er frumkvæði nemenda og sköpun ráðandi. Tekið var saman umfang pess tíma sem nemendur unnu á hverju prepi (mínútur taldar) og viðfangsefnum lýst. Meginniðurstöður leiddu í ljós að í 19\% heildartímans fengust nemendur við viðfangsefni á 3. frumkvæðisprepi (sköpun 1́ gangi) og í 23\% tímans á 2. prepi. Alls tók 1. prepið 58\% heildartímans. Jafnframt voru möguleikar nemenda til frumkvæðis greindir í premur flokkum kennsluhátta og ellefu námsgreinaflokkum. Frumkvæði í námi var nemendum almennt ekki ofarlega 1 huga. Niðurstöður gefa kennurum og skólastjórnendum tilefni til að ígrunda og endurskoða kennsluhætti í átt til meira frumkvæðis nemenda.
\end{abstract}

Efnisord: Frumkvæði, sköpun, kennsluhættir, frumkvæðiskvarði, framhaldsskóli.

\section{Inngangur}

Í lögum og aðalnámskrá fyrir framhaldsskóla er með ýmsum hætti vísað til mikilvægis frumkvæðis og sköpunar nemenda (Lög um framhaldsskóla nr. 92/2008; Mennta- og menningarmálaráðuneyti, 2011). Ætla má að pær áherslur eigi rætur í aldarlangri umræðu um pýðingu pess að nemendur hafi eitthvað að segja um náms- og kennsluhætti í stað pess að vera fyrst og fremst viðtakendur upplýsinga (Deci og Ryan, 1987; Dewey, 1916/1966; Hargreaves, 2006). Í pví sambandi er gjarnan vísað í hugtök eins og áhrif, virkni, sjálfstæði, sjálfræði, sköpun eða frumkvæði, auk nýsköpunar. Áhersla á gildi frumkvæðis og sköpunar í lífi, námi og starfi birtist víða nú á dögum, svo sem í umfjöllun um tæknipróunina, nýsköpun á tímum fjórðu iðnbyltingarinnar og færnipætti fyrir 21. öldina eða í menntastefnum (European Commission, 2006, 2016; Brynjolfsson, 2017; OECD/CERI, 2008; Reykjavíkurborg, 2018; Svanborg R. Jónsdóttir, Meyvant Dórólfsson, Jóhanna Karlsdóttir og Gunnar E. Finnbogason, 2014; Trilling og Fadel, 2009). Pótt pessir áherslupættir séu að vísu oft lítt skilgreindir má draga pá ályktun að pað sé talið mikilvægt markmið menntunar að rækta með nemendum frumkvæði. Væntanlega 
byggist pað á peirri röksemd að frumkvæði í eigin lífi, námi og starfi stuðli að velfarnaði, ábyrgð og pátttöku í mótun nærumhverfis og samfélags (Mennta- og menningarmálaráđuneyti, 2011; Patall, Cooper og Robinson, 2008).

Drátt fyrir stefnumörkun og góðan vilja hefur reynst erfitt að losa um hefðbundna stýringu kennara í skólastofunni og taka upp kennsluhætti sem gætu veitt nemendum svigrúm til einhvers konar áhrifa, frumkvæðis eða sköpunar (Gerður G. Óskarsdóttir, 2012; Ingvar Sigurgeirsson, Amalía Björnsdóttir, Gunnhildur Óskarsdóttir og Kristín Jónsdóttir, 2014; Ingvar Sigurgeirsson, Elsa Eiríksdóttir og Ingólfur Ásgeir Jóhannesson, 2018; Valgerður S. Bjarnadóttir og Guðrún Geirsdóttir, 2018). Raunar varaði Dewey (1938/2000) við pví snemma á síðustu öld að erfitt yrði að hverfa frá náms- og kennsluskipan „gamla skólans“, og kannski hefur pað reynst enn erfiðara en hann sá fyrir. Að auki virðast tilraunir til breytinga gjarnan verða skammlífar (Tyack og Cuban, 1995) og líða fyrir mikla tregðu í kerfinu (Jón Torfi Jónasson, 2016).

Í greininni er gerð tilraun til að skoða hvernig framhaldsskólar hér á landi hafa brugðist við fyrrnefndum áherslum og er stuðst við hugtakið frumkvæði. Markmiðið er að varpa ljósi á tækifæri framhaldsskólanemenda til frumkvæðis við úrlausn viðfangsefna sem kennari leggur fyrir í kennslustundum, nánar tiltekið umfang peirra og birtingarmynd (sjá mynd 1). Tilgangurinn er að skapa kennurum og skólastjórnendum ákveðin viðmið við ígrundun og endurskoðun kennsluhátta í átt til aukins frumkvæðis nemenda og tækifæra til sköpunar. Nýmæli rannsóknarinnar felst í viðfangsefni sem ekki hefur verið skoðað að neinu marki hér á landi áður, peirri nálgun sem beitt er og umfangsmiklu gagnasafni.

\section{Baksvið: Frumkvæði nemenda í orði og á borði}

Hvatinn að greininni er stefnumörkun í lögum og námskrá fyrir framhaldsskóla um frumkvæði nemenda, sem segja má að sé afrakstur víðtækrar samvinnu skólafólks, fræðimanna og stjórnmálamanna. Hér er lýst líkani sem lagt var til grundvallar athuguninni, ræett um stefnumótun, vitnað til kenninga og umfjöllunar fræðimanna sem telja má uppsprettu fyrrnefndra áherslupátta og loks drepið á niðurstöður innlendra og erlendra rannsókna um hlut nemenda í mótun námsog kennsluhátta.

\section{Frumkvæði og frumkvæðislíkan}

Hugtökin áhrif, virkni, sjálfræði, sjálfstæði, sköpun og frumkvæði koma gjarnan fyrir í námskrám og kenningum pegar fjallað er um svigrúm nemenda til að móta að einhverju marki leiðir og vinnubrögð í náminu. En pau eru misvel skilgreind og oft alls ekki og pví getur verið snúið að afmarka pau. Erfitt er til dæmis að meta hvenær nemendur hafa áhrif á vinnubrögð sín í náminu og benda má á að pau geta allt eins valið mjög hefðbundnar náms- og kennsluaðferðir og par með fest pær í sessi. Dví er ekki par með sagt að áhrif nemenda breyti nálgun í námi svo nokkru nemi. Einnig geta nemendur verið virkir án pess að leggja mikið til sjálfir, til dæmis með pví að fylgja fyrirmælum. Sama á við um hugtökin sjálfræði og sjálfstæði, en sjálfræði hefur verið skilgreint sem athafnir einstaklings í samræmi við eigin vilja og sannfæringu (Deci og Ryan, 1987; Ingibjörg V. Kaldalóns, 2015). Bæði hugtökin geta falið í sér frumkvæði og sköpun, en purfa ekki að gera pað (sbr. Hafdísi Ingvarsdóttur, 2018).

Valið var að ganga út frá hugtakinu frumkvæði, nánar tiltekið frumkvæði nemenda við úrlausn viðfangsefna, vegna pess að pað nær einna best peirri hugsun sem höfundur vildi leggja áherslu á. Ef gefa á nemendum svigrúm til að hafa eitthvað að segja um framgang námsins parf frumkvæði peirra að fá að njóta sín. Eftirfarandi skilgreining var tekin saman af höfundi til viðmiðunar við greiningu gagna: Nemendur hafa frumkvæði við úrlausn viðfangsefna pegar pau setja svip sinn á verkefni sín, vinnubrögð og framvindu námsins, svo sem með pví að tjá hugmyndir sínar í ræðu og riti eða fást, einir eða í hópi, við bókleg eða verkleg verkefni, sem ekki hafa eina fyrir fram pekkta lausn (sjá nánar líkan á mynd 1). 
Hugtökin sköpun og frumkvæði eru á vissan hátt samofin. Sköpun eða pað að vera skapandi hefur verið skilgreint sem ferli sem felur í sér að búa til eitthvað nýtt sem ekki lá fyrir áđur og bæta par með nýrri nálgun, pekkingu, skilningi eða sýn við pað sem fyrir var (Orðabanki Íslenskrar málstöðvar, e.d.). Út frá pessum hugleiðingum má segja að sköpun feli í sér frumkvæði á efsta prepi, samkvæmt priggja prepa frumkvæðiskvarðanum sem hér er lagður til grundvallar (mynd 1). En hafa verður í huga að ekki er alltaf auðvelt að sjá hvenær sköpun á sér stað. Hún er stundum mjög sýnileg, eins og pegar nemendur semja texta, skapa myndverk eða móta nýja útfærslu. Skapandi ferli sem getur átt sér stað í hugum nemenda við að fylgjast með áhugaverðum fyrirlestri, svo dæmi sé tekið, blasir aftur á móti hreint ekki við augum (Bowkett, 2005).

Til að greina tækifæri framhaldsskólanemenda til frumkvæðis við úrlausn viðfangsefna er stuðst við líkan á mynd 1 sem höfundur setti fyrst fram árið 2012 (Gerður G. Óskarsdóttir, 2012, bls. 115, 181-187, 214-221), en lagaði hér enn frekar að efninu.

\begin{tabular}{|c|c|c|c|}
\hline \multicolumn{4}{|c|}{$\begin{array}{l}\text { Frumkvæðiskvarði } \\
\text { ri nemenda til frumkvæđis við laus viðfangsefna }\end{array}$} \\
\hline & $\begin{array}{l}\text { 1. frumkvæðisprep } \\
\text { Kennarastýring }\end{array}$ & $\begin{array}{l}\text { 2. frumkvæðisprep } \\
\text { Kennari/nemendur }\end{array}$ & $\begin{array}{l}\text { 3. Frumkvæđisprep } \\
\text { Nemendastýring }\end{array}$ \\
\hline & $\begin{array}{l}\text { Engir eđa nánast engir } \\
\text { möguleikar nemenda til } \\
\text { frumkvæőis, engin sjálf- } \\
\text { stýring - ein ákveđin, pekkt } \\
\text { lausn á viơfangsefnum } \\
\text { च }\end{array}$ & $\begin{array}{c}\text { Kostur á eđa ætlast til } \\
\text { einhvers frumkvæđis } \\
\text { nemenda - val milli pekktra } \\
\text { lausna } \\
\text { V }\end{array}$ & $\begin{array}{l}\text { Frumkvæđ̄i og skōpun } \\
\text { nemenda ráđandi og peir } \\
\text { stýrandi viơ lausn viőfangs- } \\
\text { efna-engin pekkt lausn } \\
\square\end{array}$ \\
\hline $\begin{array}{l}\text { a) Hópkennsla: } \\
\text { Hlustun, áhorf, } \\
\text { spurt og svarad, } \\
\text { umræður }\end{array}$ & $\begin{array}{l}\text { Nemandi hlustar, horfir, tekur við } \\
\text { upplýsingum: Úr fyrirlestri kennara, af } \\
\text { glærum og töflu, fylgist međ yfirferø } \\
\text { (heima) verkefna }\end{array}$ & $\begin{array}{l}\text { Nemandi tekur einhvern pátt: Kennara- } \\
\text { stýrठar umræđur (gagnvirkur fyrirlestur), } \\
\text { hugarflug, spurningar og svör; ætlast til } \\
\text { viobragóa, fáir virkir }\end{array}$ & $\begin{array}{l}\text { Nemandi leggur til, tjáir sig, hefur frumkvæđi } \\
\text { og er skapandi: Nemendakynningar, umræđur } \\
\text { nemenda (allur hópurinn saman), tjá sig á eigin } \\
\text { forsendum }\end{array}$ \\
\hline $\begin{array}{l}\text { b) Einstaklings- } \\
\text { verkefni, bókleg } \\
\text { eđa verkleg }\end{array}$ & $\begin{array}{l}\text { Nemanda ætlađ̃ ađ̃ finna ákveđ̃na, } \\
\text { pekkta lausn: Vinnublöđ/ bækur (svo } \\
\text { sem býđingar; rétt-rangt spurningar); } \\
\text { reikningsdæmi; ein lausn i handverki; } \\
\text { ipróttaæfingar }\end{array}$ & $\begin{array}{l}\text { Nemandi hefur val um fleiri en eina, pekkta, } \\
\text { mögulega lausn, bvi er einhvers frumkvaeđis } \\
\text { krafist: Svo sem lýsa mynd; teikna eđa smiða } \\
\text { eftir fyrirmynd }\end{array}$ & 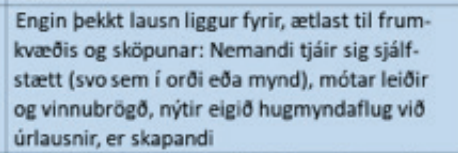 \\
\hline $\begin{array}{l}\text { c) Hóp-/para- } \\
\text { verkefni, bókleg } \\
\text { eđa verkleg }\end{array}$ & $\begin{array}{l}\text { Hópur finnur saman pekkta lausn: } \\
\text { Samtöl, söngur, keppni eftir reglum; leit } \\
\text { ađ svari i námsbók eđa á reiknings- } \\
\text { dæmi }\end{array}$ & $\begin{array}{l}\text { Hópur velur úr pekktum, fyrirliggjandi } \\
\text { lausnum: Durfa aỗ sýna nokkurt frumkvæeđi }\end{array}$ & $\begin{array}{l}\text { Samvinna i hópi; engin pekkt lausn liggur fyrir: } \\
\text { Nemendur móta saman framvindu og vinnu- } \\
\text { brögठ, eru skapandi, nýta hugmyndaflugið (i } \\
\text { nemendakynningum), takast á vió hiठ óbekkta }\end{array}$ \\
\hline
\end{tabular}

Mynd 1. Líkan byggt upp sem priggja prepa láréttur frumkvæðiskvarði til að meta tækifæri nemenda til frumkvæðis við úrlausn viðfangsefna. Á lóðréttum ási er gróf skipting kennsluhátta í prjá flokka, ásamt skilgreiningum (gert er rád fyrir að allar kennsluaðferðir rúmist innan peirra) (sjá Gerði G. Óskarsdóttur, 2012, bls. 115).

Líkanið er annars vegar byggt upp af láréttum ási með priggja prepa kvarða par sem frumkvæði nemenda er minnst eða ekkert á öðrum enda hans, pað er á fyrsta frumkvæðisprepi, en mest á hinum endanum, pað er á pví priðja, par sem frumkvæði og sköpun fær notið sín. Mitt á milli er síðan annað prepið par sem kostur er á nokkru frumkvæði. Að sjálfsögðu eru ekki skörp skil milli prepanna priggja og pau geta skarast. Dessi flokkun byggist á aðgreiningu fræðimanna á námi og kennslu í nemendastýrt og kennarastýrt nám, kennara- og nemendamiðaðar aðferðir eða óbeina og beina kennslu (sbr. Gerði G. Óskarsdóttur, 2012; Ingvar Sigurgeirsson, 2013). Hins vegar eru kennsluhættir flokkaðir í prjá flokka á lóðréttum ási í neðri hluta líkansins: a) Hópkennsla sem einkum felst í hlustun og áhorfi nemenda og umræðum, b) einstaklingsverkefni og c) samvinnuverkefni. Gert er rád fyrir að innan flokkanna priggja rúmist allar kennsluaðferðir. Í líkaninu er möguleikum nemenda til frumkvæðis innan hvers flokks lýst samkvæmt frumkvæðiskvarðanum. Hugtakið kennsluhættir (e. teaching practices, teaching approach) hefur verið skilgreint sem heildarkennsluskipulag og megineinkenni peirra kennsluaðferða 
sem notaðar eru, en kennsluaðferð (e. teaching method eða instructional method) aftur á móti sem prengra hugtak um pað skipulag „,sem kennarinn hefur á kennslu sinni, samskiptum við nemendur, viðfangsefnum og námsefni í pví skyni að nemendur læri pað sem að er keppt“ (Ingvar Sigurgeirsson, 2013, bls. 12; Ingvar Sigurgeirsson o.fl., 2014).

\section{Frumkvæði og sköpun í lögum, námskrá og menntastefnum}

Í framhaldsskólalögum frá 1988 til 2008 er lögð áhersla á nám við allra hæfi (Lög um framhaldsskóla nr. 57/1988, 2. gr.; Lög um framhaldsskóla nr. 92/2008, 2. gr.). Í lögunum frá 2008 segir einnig að framhaldsskólar skuli efla frumkvæði nemenda og leitast við að pjálfa pá í sjálfstæðum vinnubrögðum (2. gr.) og að nemendur eigi ,rétt á pví að koma á framfæri sjónarmiðum sínum varðandi ... námstilhögun“ (33. gr., breyting frá 2012).

Í aðalnámskrá framhaldsskóla frá 2011 og ritröð með henni er lýst sex grunnpáttum menntunar sem voru leiðarljós við námskrárgerðina (Mennta- og menningarmálaráđuneyti, 2011). Tveir peirra, sköpun og lýðræði og mannréttindi, tengjast umfjöllunarefni pessarar greinar. Hlutverki skólans er lýst með nokkuð afgerandi hætti í umfjöllun um sköpun í námskránni, en par segir að „skólinn skapi skilyrði par sem hvatt [sé] til frumkvæðis, sjálfstæðis og skapandi hugsunar á sem flestum sviðum“ og að sköpunarferlið stuðli að frumkvæði, ígrundun og gagnrýninni hugsun (bls. 33). Í umfjöllun um lýðræði og mannréttindi segir að forsenda lýðræðis sé meðal annars ,virkni borgaranna sem gerir pá færa um að taka pátt í að móta samfélag sitt og hafa áhrif nær og fjær" (bls. 19). Jafnframt er áréttað mikilvægi pess að í náminu sé tekið tillit til áhuga nemenda. Segja má að pátttaka í mótun samfélagsins og áhersla á áhuga nemenda hljóti að fela í sér frumkvæði með einhverjum hætti og kalli pví á ræktun frumkvæðis í skólastarfi.

Framannefnda áherslupætti má sjá í alpjóðlegri stefnumörkun um menntamál sem væntanlega hefur haft áhrifá lög og námskrár hér á landi (European Commission, 2006, 2016; OECD/CERI, 2008). Evrópusambandið hefur til dæmis skilgreint átta meginfærnipætti sem hver einstaklingur er talinn purfa að hafa á valdi sínu til að vera farsæll og virkur pjóðfélagspegn; einn peirra er „frumkvæði og sköpun“ (European Commission, 2006, 2016).

Ljóst er að skólum er ætlað að gegna stóru hlutverki í peirri viðleitni að örva frumkvæði og sköpun meðal ungmenna. Dví er vert að velta fyrir sér hvert höfundar stefnuskjala, laga og námskráa hafa sótt hugmyndir sínar um frumkvæði nemenda, skapandi hugsun og pjálfun í sjálfstæðum vinnubrögðum.

\section{Aldarlöng saga hugmynda um hlut nemenda við úrlausn viðfangsefna}

Hér verður drepið á nokkrar klassískar kenningar um kennsluhætti par sem áhersla er lögð á að nemendur hafi eitthvað að segja um útfærslu verkefna og vinnubrögð í skólastofunni og eigi par með kost á að sýna frumkvæði og sköpun. Fyrstan skal nefna John Dewey sem margir telja einn helsta menntahugsuð 20. aldar. Víða má sjá áhrif hans í kenningum innan menntunarfræði á undanförnum áratugum (Carver og Enfield, 2006; Jóhanna Einarsdóttir og Ólafur Páll Jónsson, 2010; Pring, 2017). Sem dæmi má nefna kenningar um áhrif nemenda og sjálfstæði í vinnubrögðum, valdeflingu peirra og rödd og nú á síðustu áratugum hugmyndir um einstaklingsmiðað nám (Deci og Ryan, 1987; Fletcher, 2005; Harvey og Burrows, 1992; Mitra, 2006; Tomlinson og McTighe, 2006).

Degar í upphafi 20. aldar sagði Dewey (1916/1966) að skólinn yrði að vera í stöðugri próun til að mæta breytingum á pjóðfélagi í sífelldri mótun. Hann sagði framtíðarskólann eða „nýja skólann“ einkennast af lýðræðislegum vinnubrögðum sem sköpuðu rými fyrir frumkvæði nemenda. Annars vegar gerðist pað með aðlögun að einstaklingnum og ræktun einstaklingseðlis; áhuga og hæfileikum hvers og eins skyldi mætt, pótt stundaráhugi stýrði ekki för. Hins vegar 
var sjálfstæði eða frjáls athöfn og tjáning nemandans, sem fær örvun frá félagslegu heildinni, Dewey ofarlega í huga; nemendur gerðu eitthvað af eigin hvötum - með öðrum orðum ættu frumkvæði (Dewey, 1916/1966, 1938/2000). Margir samtímamenn hans mótuðust að vonum af sama tíðaranda um aldamótin 1900 (Key, 1902/1911; Ólafur Páll Jónsson, 2010). Deir kváđu skýrt á um virkni og frumkvæði nemenda í stað utanbókarlærdóms og mikillar kennarastýringar. Í bók sinni Lýðmenntun (1903/1994) fjallar Guðmundur Finnbogason um námsgreinar og leggur áherslu á kennsluhætti sem byggist á sjálfstæðri athugun nemandans. Steingrímur Arason kom heim eftir nám í Bandaríkjunum á öðrum áratug 20. aldar með hugmyndir um kennsluaðferðir sem tóku mið af athafnasemi og áhuga barnanna (Kristín Indriðadóttir, 1995). Framan af 20. öldinni tókust síðan á hugmyndir um hlut kennara og sjálfstæði nemenda. Uppi voru sjónarmið um að nemendur ættu að hafa mikið frelsi og að draga ætti úr áhrifum hinna fullorðnu. Piaget sagði í peim anda að aðalstarf kennara væri að sjá til pess að nemendur hefðust eitthvað að, væru virkir, en kennararnir veittu aðstoð pegar á pyrfti að halda (Charles, 1982).

Á síðari helmingi 20. aldar voru áberandi kenningar um vinnubrögð í skólastarfi sem lögðu ríkt á um sjálfræði, valdeflingu eða rödd nemenda, allt pættir sem gætu falið í sér tækifæri nemenda til frumkvæðis. Með sjálfræði nemenda (e. student autonomy) er lögð áhersla á að nemendur skipuleggi nám sitt, stýri pví og meti árangurinn (Deci og Ryan, 1987). Af sama meiði eru hugmyndir um sjálfstjórnun eða sjálfstýrt nám (e. self regulated learning) (Perry, Phillips og Hutchinson, 2006; Steinunn Gestsdóttir, 2012). Valdeflingu nemenda (e. student empowerment) er ætlað að auka vald peirra í náminu, meðal annars til sjálfstæðra ákvarðana um framgang pess og vinnubrögð (Harvey og Burrows, 1992). Hugmyndir um rödd nemenda (e. student voice) fela í sér möguleika til að hafa áhrif á eigið nám (Fletcher, 2005; Rudduck, 2003). En bent hefur verið á hve ójafna möguleika nemendur hafa til að láta í sér heyra, og pað vill oft gleymast (Arnot og Reay, 2007). Dar getur komið til atgervi, stéttarstaða og vald á tungumáli skólans.

Farið var að tala um einstaklingsmiðað nám (e. individualised eða personalised learning) í lok 20. aldar, bæði austan hafs og vestan (Hargreaves, 2006; Tomlinson og McTighe, 2006) jafnt sem hér á landi (Anna Kristín Sigurðardóttir, 2007; Gerður G. Óskarsdóttir, 2003). Hugtakið hefur ekki verið vel skilgreint í íslenskri skólamálaumræðu, en í bókinni Starfshættir í grunnskólum við upphaf 21. aldar lýsa höfundar skilningi sínum á pví. Dar segir að verklag og umgjörð námsins einkennist af ólíkum viðfangsefnum nemenda eftir stöðu og áhuga, sjálfstæði peirra og áhrifum á framvindu námsins - pó ávallt innan námskrár og pess ramma sem kennari setur (Gerður G. Óskarsdóttir o.fl., 2014, bls. 323). Dessar hugmyndir eru af sama meiði og pær sem raktar eru hér framar. Hugtakið einstaklingsmiðað nám er að vísu prengra en hér er lýst í hugum sumra og annarra víðara.

Rekja má affyrrnefndum dæmum óslitinn práð hugmynda um gildi frumkvæðis, sköpunar, áhrifa, virkni eða sjálfstæðis nemenda í heila öld, allt frá Dewey til skilgreininga á einstaklingsmiðuðu námi. En spurning er hvaða áhrif pessar kenningar hafa haft í reynd á daglegt skólastarf - hvort virka námskráin sé í takt við pá áformuðu (Akker, 2003).

\section{Frumkvæði nemenda og sköpun í skólastarfi}

Kennarar virðast nota fáar aðferðir í kennslu sinni samkvæmt niðurstöðum rannsókna á kennsluháttum í grunn- og framhaldsskólum hér á landi (sjá til dæmis Hafdísi Ingvarsdóttur, 2004) og erlendis (sjá til dæmis Goodlad, 2004). Innlendar vettvangsathuganir hafa leitt 1 ljós að kynningar og fyrirlestrar kennara hafi yfirhöndina. Nemendur leysi verkefni í kjölfarið, bæði í skólanum og heima, yfirleitt allir sama verkefnið á sama tíma bæði í framhaldsskólum (Gerður G. Óskarsdóttir, 2012; Hafdís Ingvarsdóttir, 2004; Ingvar Sigurgeirsson, o.fl., 2018; Svanhildur Kr. Sverrisdóttir, 2015) og grunnskólum (Ingvar Sigurgeirsson o.fl., 2014). Reyndar var fátt um rannsóknir á kennsluháttum í íslenskum framhaldsskólum áður en verkefnið um starfshætti í framhaldsskólum, sem kynnt er í pessu riti, fór af stað og fram á síðustu ár hafa litlar upplýsingar legið fyrir um kennsluhætti hérlendis almennt. 
Lítið rými var fyrir frumkvæði nemenda í meirihluta kennslustunda á fyrstu önn í níu framhaldsskólum í Reykjavík og kennaramiðaðir kennsluhættir ráđandi, samkvæmt nýlegri rannsókn Gerðar G. Óskarsdóttur (2012). Aðeins í 10\% heildarkennslutíma sem fylgst var með (13 skóladagar, alls 61 klukkustund) höfðu nemendur tækifæri til frumkvæðis við úrlausn viðfangsefna (á 3. frumkvæðisprepi, sbr. líkan, mynd 1). Detta er eina fyrirliggjandi athugunin á tækifærum nemenda til frumkvæðis í íslenskum framhaldsskólum. Að mati reyndra kennara vilja framhaldsskólanemendur láta mata sig og gera kröfur um að peim sé „kennt“, samkvæmt rannsókn Árnýjar Helgu Reynisdóttur og Ingólfs Ásgeirs Jóhannessonar (2013). Í nýlegri rannsókn kom reyndar fram að nemendur virtust ekki reikna með pví að geta haft eða eiga að hafa einhver áhrif í námi sínu (Valgerður S. Bjarnadóttir og Guðrún Geirsdóttir, 2018). Degar nemendur voru aftur á móti markvisst vandir við að leitað væri eftir hugmyndum peirra kom fram vilji til áhrifa (Selma G. Selmudóttir, 2014).

Námsefnið og kennslubókin reyndist hið stýrandi afl og kennarar miðluðu nemendum af pekkingu sinni samkvæmt niðurstöðum Hafdísar Ingvarsdóttur (2004) um enskukennslu í framhaldsskólum og Svanhildar Kr. Sverrisdóttur (2015) um íslenskukennslu á unglinga- og framhaldsskólastigi. Hafpór Guðjónsson (2010) kemst að svipaðri niðurstöðu og segir að ríkjandi hugmyndir um einstefnumiðlun og hlutverk nemenda sem viðtakenda leiði til pess að kapp sé lagt á að komast yfir námsefnið. Engu að síður töldu tungumálakennarar að mikilvægt væri að beita skapandi aðferðum pví pær örvuðu áhuga, ykju sjálfstraust og hvettu til ábyrgðar, samkvæmt rannsókn Ástu Henriksen (2018). Tímaskortur, hefðir innan skólanna, léleg námsaðstaða og erfiðleikar við námsmat stæðu hins vegar í veginum. Einnig hefur verið sýnt fram á að skipulegt átak kennarahóps sem stendur saman að tilraun til próunar kennsluhátta í átt að auknu frumkvæði nemenda getur leitt til breytinga (Hjördís Dorgeirsdóttir, 2018).

Erlendar rannsóknir draga upp svipaða mynd og hér hefur verið gert. Sem dæmi má nefna að nemendur í bandarískum framhaldsskólum voru fyrst og fremst að hlusta á kennarann, skrifa svör við spurningum, fylla í eyður, skrifa ritgerðir eða taka próf samkvæmt niðurstöðum Goodlad (2004). Sú rannsókn byggðist á vettvangsathugunum í 1.000 bekkjum í 38 skólum á grunn- og framhaldsskólastigi, spurningalistum og viðtölum. Í tilviksrannsókn á próunarstarfi í skoskum framhaldsskóla, sem hafði pað að markmiði að efla borgaravitund með lýðræðislegum vinnubrögðum, sögðust $87 \%$ nemenda læra betur en ella pegar kennarinn reyndi að virkja pau til pátttöku (Maitles og Gilchrist, 2005).

Í fyrrnefndum íslenskum og erlendum rannsóknum voru kennarar almennt í sviðsljósinu, kenndu bekknum sem heild og tóku allar ákvarðanir um skipulag náms og kennslu. Hafdís Ingvarsdóttir (2004) ályktar að „kennarar virðast eiga pá sameiginlegu starfskenningu að peir purfi að stýra kennslunni og ef peir losi takið muni nemendur ekki vinna verkið“" (bls. 476). Dví virðist „gamli skólinn“, skotspónn Deweys, enn vera við lýði. Fyrrnefndar niðurstöður um kennsluhætti frá síðustu áratugum eru í sláandi samræmi við lýsingar Deweys hátt í öld áđur á „gamla skólanum“, sem hann sagði stjórnast af pvingun ofan frá, ytri aga og að nemendur lærðu af bókum og kennurum sem aðgerðalausir viðtakendur. Gert væri ráð fyrir að pvinga eða lokka pyrfti nemendur til náms og æetlast til að peir innbyrtu námsefnið í fyrirskipuðum skömmtum (Dewey, 1938/2000; í: Jóhanna Einarsdóttir og Ólafur Páll Jónsson, 2010). Dótt námsefnið hefði mikil áhrif á kennsluhættina var hann með pessari gagnrýni ekki að draga úr mikilvægi pess (Ólafur Páll Jónsson, 2010). Hlýðni hefði orðið sá kvarði sem nemandinn væri mældur eftir, sagði Dewey, pó „að frumkvæði, frumleiki og sjálfstæði [væru] dýrmætari eiginleikar í lífinu“" (í: Jóhanna Einarsdóttir og Ólafur Páll Jónsson, 2010, bls. 200) og ófélagslegt eðli hefðbundna skólans mæetti sjá á pví að hann hefði gert „,pögnina að einni af höfuðdygðum sínum“ (Dewey, 1938/2000, bls. 73) - lýsing sem enn getur átt við. Niðurstöður rannsókna hér á landi jafnt sem erlendis á kennsluháttum benda pví ekki til pess að hugmyndir um að nemendur hafi eitthvað um framkvæmo námsins að segja hafi að neinu marki náð inn í daglegt skólastarf.

Í stuttu máli hefur skólafólk, stjórnmálamenn og fræðimenn í um eina öld lagt áherslu á áhrif nemenda, sjálfstæði peirra, sköpun og frumkvæði í lögum, námskrám og fræðiritum - raunar 
frá mismunandi fræðilegu sjónarhorni. Engu að síður virðast kennaramiðaðir starfshættir hafa yfirhöndina. Litlar upplýsingar liggja fyrir um náms- og kennsluhætti í íslenskum framhaldsskólum yfirleitt og enn síður um möguleika nemenda peirra á að sýna frumkvæði um vinnubrögð eða leiðir við úrlausn viðfangsefna. Dví pótti áhugavert og mikilvægt að beina sjónum að framhaldsskólanemendum og kanna sérstaklega tækifæri peirra til frumkvæðis við úrlausn viðfangsefna - í ljósi ákvæða í lögum og námskrá og aldarlangrar fræðilegrar umræðu. Settar voru fram eftirfarandi rannsóknarspurningar:

- Hvert er umfang og birtingarmynd tækifæra framhaldsskólanemenda til frumkvæðis við úrlausn viðfangsefna sem kennari leggur fyrir í kennslustundum (samkvæmt greiningu á frumkvæðisprepi, tímalengd og kennsluháttum) og hvernig kemur munur milli skóla, kennsluhátta og námsgreina fram í pessum efnum?

- Hvert er sjónarhorn nemenda á tækifæri sín til frumkvæðis í kennslustundum?

\section{Framkvæmd rannsóknarinnar}

Dessi athugun er hluti af rannsóknarverkefninu Starfsháttum 1 framhaldsskólum sem fram fór í níu framhaldsskólum um landið, en peir voru valdir sem lagskipt slembiúrtak (sjá nánar um framkvæmd: Gerður G. Óskarsdóttir og rannsóknarhópur um starfshætti í framhaldsskólum, 2018) [1]. Í pessari athugun er unnið úr umfangsmiklum vettvangslýsingum og viðtölum við nemendahópa. Fimmtán rannsakendur unnu að gagnaöfluninni.

\section{Vettvangslýsingar og hópviðtöl við nemendur}

Byggt er á vettvangslýsingum á 130 kennslustundum sem voru samtals um 167 klukkustundir. Lengd stundanna var frá 40 mínútum upp í um fjórar klukkustundir, en langflestar peirra (82\%) stóðu í 40 til 80 mínútur. Kennslustundir voru valdar með pví að fylgja nemendum af mismunandi námsbrautum eftir. Fylgt var að minnsta kosti einum nemanda eða bekk á hverju námsári í öllum skólunum, en tveimur til premur nemendum í stærri skólum og skólum með starfsnámsbrautir. Ýmist voru einn eða tveir athugendur í hverri kennslustund, einn í 73 stundum en tveir í 57 peirra, sem skráđu vettvangslýsingu sameiginlega. Athugendur skráđu athugun sína á par til gert skráningareyðublað. Lýsing á kennslustund skiptist í tvo dálka, annar var fyrir pað sem kennari gerði og hinn fyrir framlag nemenda. Lýsingunni var fylgt eftir með stuttri samantekt og hugleiðingum athuganda.

Auk pessa er stuðst við viðtöl við 17 nemendahópa með samtals 56 nemendum, 18 ára og eldri, sem buðu sig fram til pátttöku í kennslustundum sem heimsóttar voru. Fimm rannsakendur skiptu með sér ábyrgð á nemendaviðtölunum og fylgdu viðtalsramma sem mótaður var af rannsóknarhópnum. Í rammanum var kafli með spurningum um möguleika nemenda til að hafa áhrif á námið og stýra pví, sýna frumkvæði eða láta hugmyndaauðgina njóta sín. Reynt var að útskýra nánar fyrir viðmælendum hvað átt væri við með hugtakinu frumkvæði.

\section{Greining gagna}

Við greiningu vettvangslýsinganna var beitt bæði eigindlegri og megindlegri nálgun. Leitast var við að greina að hvaða marki (prjú frumkvæðisprep), hve lengi (í mínútum talið) og við hvaða aðstæður (birtingarmynd í premur kennsluháttaflokkum) nemendur áttu pess kost að sýna frumkvæði í kennslustundum.

Stuðst var við líkan sem lýst er hér framar á mynd 1 (Gerður G. Óskarsdóttir, 2012) til að meta að hvaða marki nemendur ættu pess kost að sýna frumkvæði og við hvaða aðstæður. Líkanið skiptist annars vegar í priggja prepa láréttan frumkvæðiskvarða (efri hluti líkans) og hins vegar í prjá grófa flokka kennsluhátta á lóðréttum ási par sem lýst er birtingarmynd frumkvæðis innan peirra (neðri 
hluti líkans). Gert er ráð fyrir að innan kennsluháttaflokkanna priggja geti allar kennsluaðferðir rúmast og undir hvern flokk falli pví margs konar kennsluaðferðir (Ingvar Sigurgeirsson, 2013; Ingvar Sigurgeirsson o.fl., 2014). Fyrst var hver vettvangslýsing greind í kennsluháttaflokkana prjá í líkaninu (eigindleg nálgun): a) Hópkennsla, b) einstaklingsverkefni og c) samvinnuverkefni. Síðan var greint samkvæmt skilgreiningum á lárétta kvarðanum á hvaða prepi eða prepum nemendur unnu (eigindleg nálgun). Í einstaka tilfellum gat verið álitamál hvernig átti að flokka par sem ekki eru skörp skil milli frumkvæðisprepanna eða kennsluháttaflokkanna priggja.

Til að meta nánar umfang tækifæra nemenda til frumkvæðis var heildarmínútufjöldi á hverju frumkvæðisprepi tekinn saman og einnig fjöldi mínútna á hverju prepi innan hvers kennsluháttaflokks (megindleg nálgun). Yfirleitt skráđu athugendur tímann á um fimm mínútna fresti í vettvangslýsingunum, en ef pað var ekki gert purfti að áætla tímann að einhverju leyti. Hér er pví ekki um nákvæma greiningu á tímalengdum að ræða í pessum 130 kennslustundum, en pó nógu nákvæma til að greiningin gefi mynd af pví sem ætlað var að varpa ljósi á. Loks voru valin dæmi til birtingar af hverju prepi í hverjum kennsluháttaflokki sem póttu lýsa vel pví frumkvæðisprepi og peim aðstæðum eða birtingarmynd frumkvæðis sem um ræðir hverju sinni.

Til að draga fram sjónarhorn nemenda var annars vegar leitað eftir vísbendingum um frumkvæði og sköpun við úrlausn viðfangsefna í svörum við fyrrnefndum spurningum í nemendaviðtölunum og hins vegar viðhorfum peirra til áhrifa í náminu.

Höfundur átti von á að frumkvæði nemenda ykist pegar liði á námið í framhaldsskólanum og nemendur urðu eldri og proskaðri (sbr. Árnýju Helgu Reynisdóttur og Ingólf Ásgeir Jóhannesson, 2013; Gerði G. Óskarsdóttur, 2012) og skipting milli frumkvæðisprepanna priggja gæti orðið nokkuð jöfn pegar á heildina væri litið.

\section{Niðurstöður}

Hér er fyrst lýst umfangi tækifæra nemenda til frumkvæðis í 130 kennslustundum á grunni vettvangslýsinga, pað er að hvaða marki (samkvæmt priggja prepa frumkvæðiskvarða í líkani á mynd 1) og hve lengi (í mínútum talið) nemendur áttu kost á að sýna frumkvæði. Greint er frá mun á milli skóla. Pá er fjallað um viðhorf nemenda til frumkvæðis á grunni 17 hópviðtala. Dví næst er rætt um umfang og birtingarmynd frumkvæðis nemenda innan kennsluháttaflokkanna priggja (sbr. neðri hluta líkans, mynd 1). Umfangið er borið saman og kynnt dæmi um birtingarmynd frumkvæðis nemenda, fengin bæði úr vettvangslýsingum og nemendaviðtölum. Loks er hugað að mun eftir námsgreinum í pessum efnum.

\section{Umfang frumkvæðis nemenda - prjú frumkvæðisprep og tímalengd}

Heildartími á hverju af frumkvæðisprepunum premur í kennslustundunum 130 samanlagt var tekinn saman. Fyrsta frumkvæðisprepið tók greinilega mestan tíma, eins og sést á mynd 2, eða tæplega helming heildartímans sem fylgst var með (um 47\%). Vinnubrögðin einkenndust af pví að nemendur tóku við upplýsingum eða fengust við einstaklings- eða hópverkefni sem fólu í sér leit að pekktri lausn. Viðfangsefni nemenda gáfu ekkert eða nánast ekkert ráðrúm til frumkvæðis. Upphaf og lok kennslustunda tóku rúmlega tíunda hluta heildartímans (11\%) og má flokka hann á 1. prepinu. Dá voru nemendur að koma sér fyrir í kennslustofunni, svara nafnakalli, hlusta á inngangsorð kennara eða ganga frá og fá upplýsingar um próf og heimanám. Par með spannaði 1. prepið hátt í 60\% af heildartímanum (58\%) (sjá nánari lýsingu í dæmum hér síðar).

Á 2. frumkvæðisprepi áttu nemendur kost á nokkru frumkvæði og var tæplega fjórðungur tímans (23\%) skilgreindur á pví. Um var að ræða kennarastýrðar umræður og einstaklings- eða hópverkefni sem buðu upp á val um pekktar lausnir (sjá dæmi hér síðar). 
Aðeins um fimmtugur (19\%) heildartímans var á 3. prepi. Pað fólst í nemendastýrðum umræðum eða einstaklings- og hópverkefnum með enga pekkta lausn. Detta er prepið par sem frumkvæði og sköpun nemenda fær notið sín (sjá dæmi hér síðar).

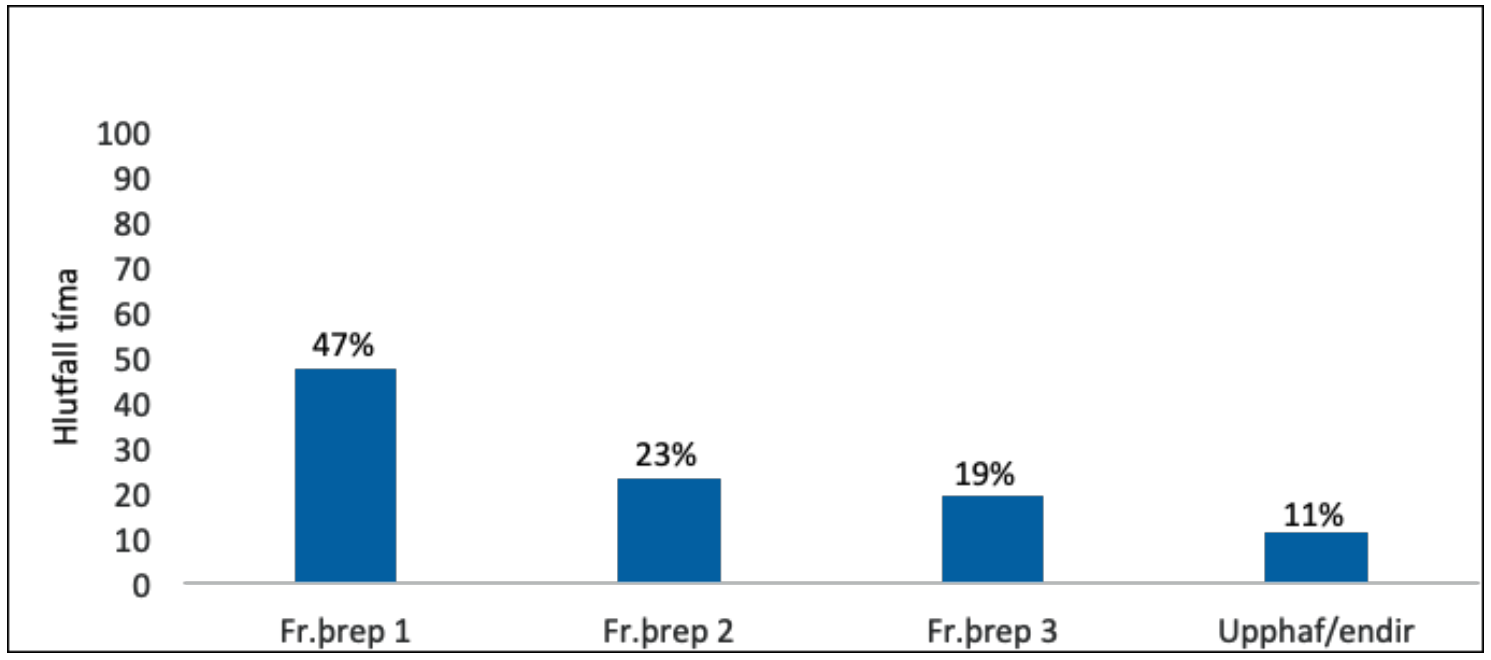

Mynd 2. Hlutfall tíma (mín.) á premur frumkvæðisprepum (sbr. efri hluta líkans, mynd 1).

Skoðaður var munur á milli byrjunaráfanga (alls 47 stundir af 130 kennslustundum) og framhaldsáfanga (83 kennslustundir), til að kanna hvort frumkvæði nemenda við lausn viðfangsefna ykist pegar liði á námið og nemendur væru orðnir eldri og proskaðri. Athygli vakti að ekki kom fram munur par á. Pannig virtust tækifæri til frumkvæðis ekki aukast pegar lengra leið á námið.

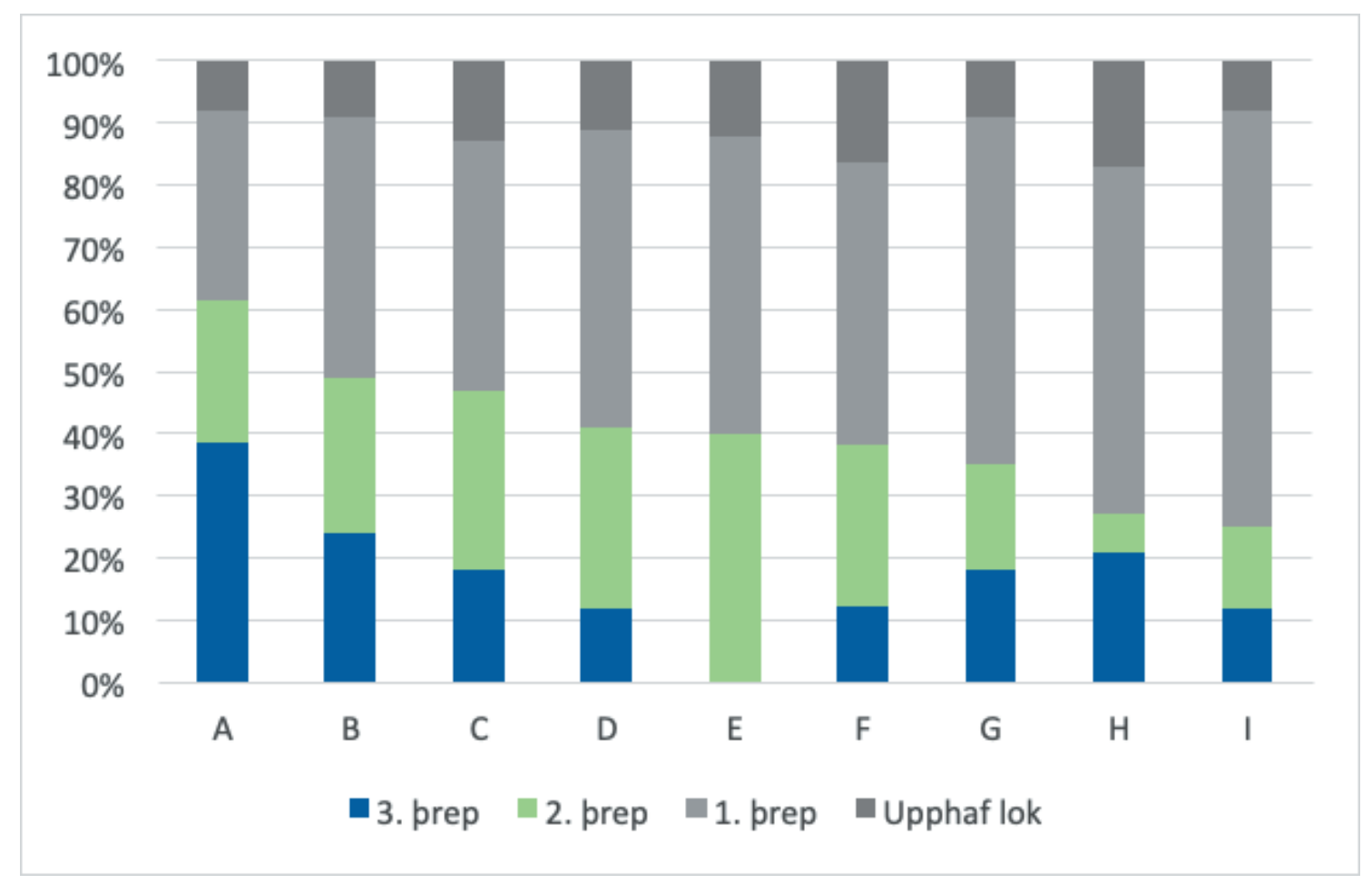

Mynd 3. Hlutfall tíma á premur frumkvæðisprepum eftir skólum (níu skólar merktir með bókstöfum). 
Talsverður munur birtist milli skólanna níu í pessum efnum (mynd 3). Mestir möguleikar nemenda til frumkvæðis voru í skóla par sem tæplega 40\% heildartímans voru greind á 3 . frumkvæðisprepi (skóli A á mynd 3) og 23\% á öđru prepi, eða samtals 63\% heildartímans á 2. og 3. frumkvæðisprepi. Aftur á móti greindist enginn tími á 3. prepinu í einum skólanna (skóli E) og 1. prepið tók hátt í prjá fjórðu heildartímans sem fylgst var með í tveimur peirra (skólar H og I). Í pessu sambandi verður pó að hafa í huga að ekki var um sambærilegar kennslustundir að ræða milli skólanna (mismunandi námsgreinar). Munur á skólum í pessum efnum bendir pó til pess að skólar séu ólíkir hvað varðar tækifæri nemenda til frumkvæðis.

\section{Sjónarhorn nemenda}

Í nemendaviðtölunum (17 að tölu, alls 56 nemendur) kom ekki fram áberandi áhugi á að marka leiðir eða móta vinnubrögð í meiri mæli en nemendur áttu að venjast. Pó voru dæmi par um, eins og orð eins viðmælanda bera vott um:

Mér finnst ... of mikið verið að setja alla inn í sama kassann ...fólk æetti meira að fá að velja hvað pað gerir. ... hvernig pað vinnur í tímum ... a pví að pað ... læra ekkert allir eins.

Degar spurt var um möguleika á að láta hugmyndaauðgina njóta sín, tjá sig og hafa áhrif á hvernig verkefni er unnið eða útkoma mótuð komu svör sem bentu til frumkvæðis: „Já, oft getur maður раð. ... Kannski, ef maður er svona smá sniðugur, breytt aðeins verkefninu ... skrifað um eitthvað aðeins öđruvísi en spurningin var akkúrat.“ Nemandi í iðnnámi sagði frá sjálfstæðri vinnu við lokaverkefni: „Đá var voðalega mikið byggt upp á pví bara, ... eins og sveinsprófsverkefnið, ... að hanna, smíða, eitthvað tæki frá grunni. Đá var pað bara alveg okkar,“ og bætti við: „Đá erum við í raun, ekki einu sinni, pannig séð ... með neinn kennara." Viðmælandi lýsti pví hvernig ætlast væri til að nemendur skipulegðu sjálf hraðann í skilum á verkefnum hverrar viku: Dau „opna öll verkefni á mánudegi og pú parft að skila peim öllum á sunnudegi ... ég reyni alltaf að vera búin með allt á föstudögum." Dannig virtist nemandinn njóta pess að geta að vissu marki stýrt skilum verkefna. Margir nemendur nefndu valfrelsi sitt um fyrirkomulag nemendakynninga: „Já, pað eru mjög oft svona ... myndband, plakat, kynning, powerpoint, ritgerð, bara hvað hentar hverjum." Í pessu tilfelli virtist vera val um margar leiðir en pó aðeins nefndar nokkuð hefðbundnar leiðir. Annar nefndi skilaverkefni: „Fáum bara fimm, sex hugmyndir og síðan bara getum við valið eina af peim.“ En í einum hópi kom svarið: „Ég geri bara pað sem mér er sagt.“ Svörin bentu almennt séð hvorki til pess að nemendur fengju mikið svigrúm til frumkvæðis eða sköpunar né að peim fyndist eðlilegt að svo væri.

Af pessum niðurstöðum má í stuttu máli ráđa að nemendur hafi verið í talsvert meiri mæli piggjendur upplýsinga en að lögð væri áhersla á frumkvæði peirra eða sköpun. Fyrsta frumkvæðisprepið virtist vera ráđandi í hugum peirra og lýsingar á vinnubrögðum bentu í sömu átt. Pannig töldu viðmælendur sig ekki eiga mikið frumkvæði við lausn viðfangsefna og virtust varla átta sig á að pess væri kostur, sáu tæplega fyrir sér priðja prepið. Hér réðu að sjálfsögðu peir kennsluhættir sem kennarar völdu, en ráða má af svörum nemenda að kennarar hafi verið nær einráđir um kennsluhættina.

\section{Umfang og birtingarmynd frumkvæðis í premur flokkum kennsluhátta}

Ípessumkaflaverðurfyrstlýstumfangifrumkvæðisnemendainnanhversafkennsluháttaflokkunum premur, annars vegar út frá greiningu á frumkvæðisprepin prjú og hins vegar tímalengd (í mínútum talið). Jafnframt er varpað ljósi á mun milli flokkanna í peim efnum. Dví næst eru kynnt valin dæmi úr vettvangslýsingum og viðtölum við nemendur sem sýna birtingarmynd frumkvæðis í hverjum flokki fyrir sig og pannig fyllt enn frekar inn í myndina (sjá skilgreiningar ílíkani á mynd 1). 


\section{Drír kennsluháttaflokkar - frumkvoeisprep og tími}

Á töflu 1 má sjá annars vegar hvernig heildartími nemenda í kennslustundunum 130 skiptist á milli fyrrnefndra priggja flokka kennsluhátta (annar dálkur) og hins vegar möguleika nemenda til frumkvæðis innan hvers peirra samkvæmt greiningu á frumkvæðiskvarðanum (priðji til fimmti dálkur).

Tafla 1. Drír flokkar náms- og kennsluhátta og prjú frumkvæðisprep (130 kennslustundir).

\begin{tabular}{lcccc}
\hline Flokkar kennsluhátta & $\begin{array}{c}\text { Hlutfall } \\
\text { flokks af } \\
\text { heildartíma }\end{array}$ & $\begin{array}{c}\mathbf{1 .} \\
\text { frumkvæðis- } \\
\text { prep }\end{array}$ & $\begin{array}{c}\mathbf{2 .} \\
\text { frumkvæðis- } \\
\text { prep }\end{array}$ & $\begin{array}{c}\mathbf{3 .} \\
\text { frumkvæðis- } \\
\text { prep }\end{array}$ \\
\hline $\begin{array}{l}\text { a) Hópkennsla: Hlustun, } \\
\text { áhorf og umræður, (par } \\
\text { með talið upphaf og lok }\end{array}$ & $46 \%$ & $37 \%$ & $7 \%$ & $2 \%$ \\
$\begin{array}{l}\text { kennslustundar) } \\
\text { b) Einstaklingsverkefni }\end{array}$ & $37 \%$ & $18 \%$ & & \\
c) Hóp- eða paraverkefni & $17 \%$ & $3 \%$ & $10 \%$ & $9 \%$ \\
\hline & $100 \%$ & $58 \%$ & $6 \%$ & $8 \%$ \\
\hline
\end{tabular}

Ef litið er á annan dálk í töflu 1 sést að í tæplega helming heildartímans (46\%) voru nemendur að taka við upplýsingum, hlusta á útskýringar eða fyrirlestur, horfa á myndband eða taka pátt í skipulögðum umræðum alls hópsins (flokkur a). Upphaf og lok kennslustunda, um 11\% af heildartímanum, eru meðtalin. Nokkuð yfir priðjungur tímans fór í að vinna einstaklingsverkefni (37\%, flokkur b). Nemendur unnu síðan saman að einhvers konar para- eða hópverkefnum í um 17\% af heildartímanum (flokkur c). Minnt er á að innan hvers flokks eru margvíslegar kennsluaðferðir.

Skipting á frumkvæðisprepin prjú innan hvers flokks náms- og kennsluhátta er sýnd annars vegar í töflu 1 sem hlutfall pess heildartíma sem fylgst var með (dálkar prjú til fimm) og á mynd 4 sem hlutfall af heildartíma hvers flokks fyrir sig.

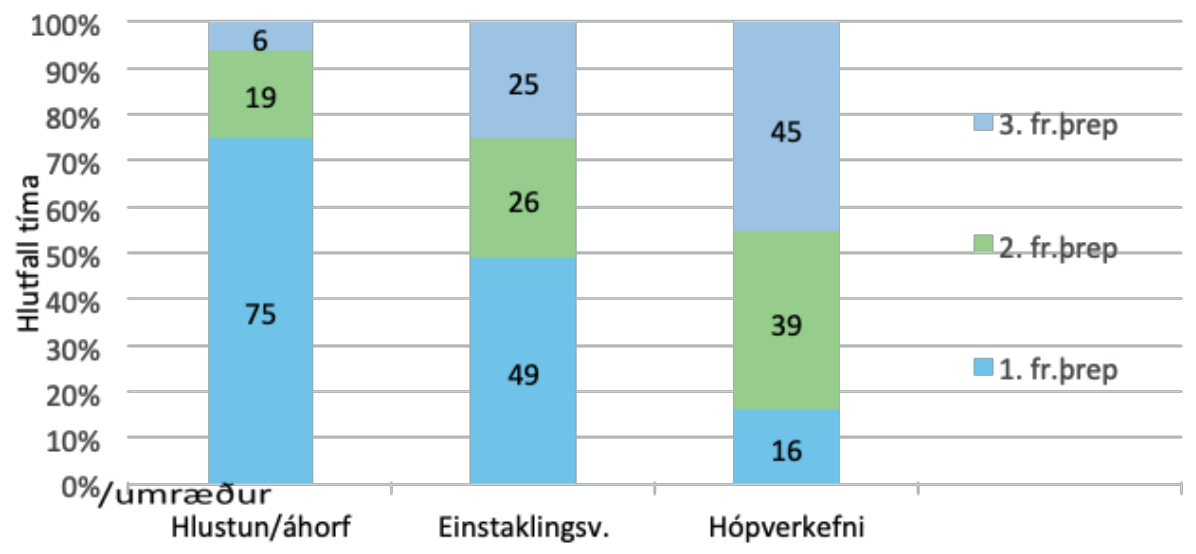

Mynd 4. Hlutfall priggja frumkvæðisprepa innan hvers af premur flokkum kennsluhátta (sbr. líkan, mynd 1).

Í flokki sem hér er kallaður hópkennsla (flokkur a) reyndust möguleikar til frumkvæðis minnstir, sem kom ekki á óvart. Frumkvæði kom aðallega fram í viðræðum við kennara, sem gátu falist 1 svörum við spurningum kennara eða spurningum nemenda (2. prep), en einnig í umræðum milli nemenda og kynningum peirra (3. prep). Mikla eftirtekt vakti sá litli tími sem virtist varið í umræður milli nemenda um ákveðið málefni eða aðeins um $2 \%$ heildartímans. Einstaklingsverkefni (flokkur b) buðu upp á mun fleiri tækifæri til frumkvæðis en sá flokkur. En athyglisverðast var að möguleikarnir virtust mestir í hópverkefnum (flokkur c). Nemendur unnu á 2. og 3. frumkvæðisprepi í 84\% tímans sem fór í hópvinnu (sjá töflu 1 og mynd 4). 
Til að draga nánar fram birtingarmynd frumkvæðis nemenda í kennsluháttaflokkunum premur verða nú rakin dæmi úr vettvangslýsingum og viðtölum við nemendur (dæmi um öll frumkvæðisprepin prjú í hverjum flokki).

\section{Flokkur a: Hópkennsla - hlustun, áhorf og umraður (46\% heildartímans) - domi}

Frumkvæði nemenda var minnst í flokknum hópkennsla, eins og fyrr segir (um 75\% á 1. frumkvæðisprepi; mynd 4). Dæmi um hlustun á 1. prepi var í kennslustund í stærðfræði par sem unnið var með hornaföll og stuðst við kennslubók. Í vettvangslýsingu segir:

Farið er í hvert dæmið á eftir öðru á töflu, kennari hefur orðið nánast allan tímann, útskýrir og spyr en svarar sér gjarnan sjálfur. ... Kennari skrifar gjarna útskýringar á töfluna, talar á meðan og færir sig síðan aftar í stofu og útskýrir pað sem stendur á töflunni.

Viðhorf nemenda til pessa flokks almennt voru fremur neikvæð. Gjarnan töldu pau fyrirlestra með glærusýningum ekki bera pann árangur sem kennarar ætluðu, eða eins og pað var orðað: „Mér finnst voða mikið af tímunum hérna pannig að pú getur alveg eins lesið petta heima hjá pér og ert helmingi fljótari að pví, pannig að pað er oft voða tilgangslaust að vera í tímum.“ Annar nemandi kvartaði yfir pví að purfa alltaf að sitja, hlusta og skrifa.

Í kennslustund í félagsfræði var horft á myndband um kynbundið ofbeldi, dæmi um áhorf á 1. prepi. Myndin hélt vel athygli nemenda stóran hluta tímans. Nemendur áttu að skrá ígrundun sína í ferlimöppu, en ekki rekja sögupráðinn (3. prep). Kennari stöðvaði myndina öðru hvoru til að skjóta inn skýringum, spyrja spurninga eða vekja umræðu. Í umræðum á eftir milli kennarans og einstakra nemenda greip kennarinn yfirleitt orðið pegar pað losnaði pannig að ekki var um umræður milli nemenda að ræða (voru umræður á 2. prepi).

Undir umræðum í kennslustund í uppeldisfræði um eftirlitsmyndavélar naut frumkvæði nemenda sín -á 3. prepi. Kennarinn byrjaði með ögrandi spurningu um pað hversu æskilegt væri að hafa eftirlitsmyndavélar í kennslustofum. Hún bað nemendur að taka afstöðu til spurningarinnar og raða sér síðan í stofuna samkvæmt henni, ýmist aftast, fremst eða í miðju. Í samantekt í lok vettvangslýsingar skrifar rannsakandi:

Nemendur mjög virkir í umræðunni. K dregur saman í lokin og tengir við markmið áfanga og næstu verkefni ... K hlustar vel á nemendur, heldur sig mikið til hlés ... K tókst að fá nemendur til að tjá sig, næstum alla, beita rökum og komast að niðurstöðu.

Viðmælandi í einu nemendaviðtalinu lýsti bestu kennsluaðferðinni að sínu mati: „Glósur úr pví frá kennurum og síðan umræður eru eiginlega best,“ og sagði frá dæmi úr umræðum um príhyrninginn í stærðfræðitíma par sem nemendur gátu tjáð sig og spurt spurninga og bætti við: „Svona umræðutímar eru mjög góðir.“"

Nemendakynningar á 3. og 1. prepi fóru fram í 10 kennslustundum af 130. Pá höfðu nemendur tóm til frumkvæðis við úrlausn viðfangsefnis. Í einni pessara stunda var fjallað um siðfræði líffræðinnar. Fjórir nemendahópar kynntu niðurstöður sínar með glærum og myndskeiðum, aðrir glósuðu og áttu að skila glósum á vef. Kennari spurði flytjendur ögrandi siðferðilegra spurninga. Deir sem kynntu voru yfirleitt að vinna á 3. prepi par sem peir kynntu með eigin orðum vinnu sem peir höfðu haft frumkvæði að, en hinir fylgdust með á 1. prepi. Viðmælandi í einum nemendahópnum lýsti nemendakynningu í kynjafræði og rannsakandi sem tók viðtalið bætti við: „Já, ég heyrði pað, [kennarinn] hvatti mikið til pess að pið létuð frumkvæðið njóta sín og vera frumleg og pað [væri] best að vera sem óvenjulegastur ... besta einkunnin.“ 


\section{Flokkur b: Einstaklingsverkefni (37\% heildartímans) - doemi}

Fyrsta frumkvæðisprepið var einnig umfangsmest 1 einstaklingsverkefnum (um helmingur tímans), en fjórðungur var á 2. prepi og annar fjórðungur á pví priðja (mynd 4).

Dæmi um einstaklingsverkefni á 1. prepi var í kennslustund í bókfærslu. Nemendur sóttu verkefni og lausnir á netið. Kennari gekk á milli og útskýrði öðru hvoru einstök dæmi á töflu. Í vettvangsnótum segir: „Kennari allur af vilja gerður til að koma til móts við nemendur, svo sem fara betur í pað sem pá vantaði ... peir sem vildu vinna og nýta tímann gerðu pað, en meirihluti nemenda var óvirkur.“ Nemendur voru ýmist í símanum eða á netinu.

Nefna má kennslustund í myndmennt sem dæmi um einstaklingsverkefni á 2. prepi par sem allir teiknuðu borðsíma eftir fyrirmynd en réðu útfærslunni. Kennarinn gekk á milli og aðstoðaði. Annað dæmi var kennslustund í æfinga- og tækjasal. Nemendur drógu spil með æfingum sem reyndu á pol í ýmsum tækjum, svo sem að snúa, hoppa, snerta gólf eða gera armbeygjur - og gera átti petta hratt og taka tímann. Aðrir æfðu sig í róðrartæki, kraftlyftingatæki eða á hlaupabretti. Kennari hvatti nemendur áfram, skipaði fyrir og dreifði á mismunandi tæki.

Dæmi um einstaklingsverkefni á 3. prepi var í kerfisstjórnun. Dað fólst í pví að nemendur hönnuðu tölvukerfi frá grunni út frá lýsingu á gervifyrirtæki. Par voru skilgreind nöfn og hlutverk hinna ýmsu stjórnenda og hversu mikinn eða lítinn aðgang peir áttu að hafa að fjölbreyttum upplýsingum. Athugandi skrifaði: „Gott dæmi um hvað nemendur eru vinnusamir pegar peir ... fást við verkefni sem höfða til peirra og peir sjá tilgang með.“ Nemendur töluðu vel um slík verkefni: „Фví maður lærir miklu meira á að gera verkefni sjálfur ... heldur en að hlusta, pví pað getur bara farið inn um eitt eyrað og út um hitt.“ Hér vísar viðmælandi væntanlega til möguleika sinna til að sýna frumkvæði.

\section{Flokkur c: Hópverkefni (17\% heildartímans) - dami}

Frumkvæði nemenda fékk greinilega best notið sín í hópverkefnum, en athygli vakti að nær helmingur tímans innan pess flokks var greindur á 3. prepi (45\%), og aðeins minni tími á 2. prepi (um 39\%), eða samtals 84\%, eins og fyrr segir (mynd 4). En nemendur lögðu greinilega mismikla vinnu fram í hópnum eða skiptu með sér verkum.

Dæmi um hópverkefni á 1. prepi var í ensku par sem nemendur voru að rifja upp orðaforða úr textum sem lesnir höfðu verið. Deir unnu saman í hópum við að para saman útklippt orð á ensku og íslensku. Degar allir höfðu parað saman orðin fóru fulltrúar úr hverjum hópi í annan hóp til að pess að fara yfir pörunina. Kennari sýndi síðan nemendum rétt svör á glæru. Nemendur voru virkir en purftu ekki að sýna frumkvæði við lausn verkefnisins.

Í efnafræði par sem nemendur unnu á nokkrum starfsstöðvum, um fjórir nemendur í hópi, var dæmi um hópverkefni á 2. prepi. Viðfangsefnið var útreikningar á massa og efnismagni, fjölda efnisagna og fleira. Hóparnir voru með kassa með efnafræðibókum, formúlublöðum og áætlunum sem peir fylgdu. Nemendur ræddu saman um mögulegar lausnir. Kennarinn benti á að pað væri fleiri en ein leið að réttu svari. „Kennarinn ögraði nemendum sífellt og leiddi pá áfram í vinnu sinni. Áhugavert var að sjá hversu samvinnupýðir og virkir nemendur voru í kennslustundinni,“ segir í vettvangslýsingu. Parna fékk frumkvæði nemenda að njóta sín að ákveðnu marki (á 2. prepi), en minnt er á að virkni parf ekki að hafa frumkvæði í för með sér.

Dæmi um hópverkefni á 3. prepi var í ípróttafræði par sem nemendur unnu í hópum að pví að skipuleggja ípróttaskóla. betta var priggja vikna verkefni sem bauð „upp á töluvert frjálsræði og sköpun nemenda innan ákveðins ramma og nemendur virtust almennt áhugasamir ... [stundin hafði] yfirbragð vinnusemi án mikillar íhlutunar kennara," sagði athugandi í vettvangslýsingu. Dótt verkefni í hópvinnu krefjist frumkvæðis getur vel verið að aðeins sumir nemendur taki málin 1 sínar hendur og aðrir sitji frumkvæðislausir á hliðarlínunni. 
Af pessum dæmum má sjá að umræddir prír flokkar kennsluhátta buðu upp á mismunandi tækifæri nemenda til frumkvæðis, en pað virtist hafa verið í höndum kennaranna að skapa pau tækifæri. Sá munur sem fram kom á einstaklings- og hópverkefnum var einna eftirtektarverðastur. Dá vaknar sú spurning hvort munur sé á námsgreinum í pessum efnum.

\section{Námsgreinar - munur á frumkvæði}

Skoðuð voru tækifæri nemenda til frumkvæðis í einstökum námsgreinaflokkum til að varpa ljósi á hugsanlegan mun á milli greina (tafla 2). Námsgreinar sem fylgst var með í kennslustundunum 130 voru flokkaðar í ellefu flokka (sbr. Gerði G. Óskarsdóttur og rannsóknarhópur um starfshætti 1 framhaldsskólum, 2018, tafla 2). Hér verður reyndar að hafa í huga að mikill munur var á fjölda kennslustunda sem fylgst var með í námsgreinaflokkunum (annar dálkur í töflu 2) og að námsgreinar geta verið ólíkar í eðli sínu hvað varðar möguleika til frumkvæðis. Detta dregur úr gildi samanburðarins, en engu að síður gefur hann ákveðnar vísbendingar.

Tafla 2. Námsgreinar (130 kennslustundir) - frumkvæði. Hlutfall tíma flokkað samkvæmt priggja prepa frumkvæðiskvarða (til glöggvunar eru tölur feitletraðar ef pær voru vel yfir meðaltali).

\begin{tabular}{|c|c|c|c|c|c|c|c|}
\hline Námsgreinaflokkur & $\begin{array}{c}\text { Fjöldi } \\
\text { kennslu- } \\
\text { stund }\end{array}$ & $\begin{array}{l}\text { Upphaf } \\
\text { og lok }\end{array}$ & $\begin{array}{c}1 . \\
\text { frum- } \\
\text { kvæðis- } \\
\text { prep }\end{array}$ & $\begin{array}{c}2 . \\
\text { frum- } \\
\text { kvædis- } \\
\text { prep }\end{array}$ & $\begin{array}{c}3 . \\
\text { frum- } \\
\text { kvædis- } \\
\text { prep }\end{array}$ & $\begin{array}{c}\text { (2. og } 3 . \\
\text { frumkvæðis- } \\
\text { prep) }\end{array}$ & Samtals \\
\hline & & $\%$ & $\%$ & $\%$ & $\%$ & $\%$ & $\%$ \\
\hline Alls, allar greinar & 130 & 11 & 47 & 23 & 19 & $(42)$ & 100 \\
\hline $\begin{array}{l}\text { Erlend tungumál (alls } \\
\text { fimm tungumál) }\end{array}$ & 20 & 11 & 51 & 17 & 21 & (38) & 100 \\
\hline $\begin{array}{l}\text { Félagsvísindagreinar } \\
\text { (félags-, uppeldis- og } \\
\text { viðskiptafræði, lífsleikni) }\end{array}$ & 18 & 15 & 49 & 19 & 17 & (36) & 100 \\
\hline $\begin{array}{l}\text { Hugvísindagreinar (saga og } \\
\text { heimspeki, p.m.t. siðfræði) }\end{array}$ & 11 & 9 & 58 & 12 & 21 & (33) & 100 \\
\hline $\begin{array}{l}\text { Iðn- og starfsnámsgreinar } \\
\text { (bóklegar og verklegar) }\end{array}$ & 18 & 9 & 47 & 33 & 11 & (44) & 100 \\
\hline Íslenska & 12 & 15 & 25 & 30 & 30 & $(60)$ & 100 \\
\hline $\begin{array}{l}\text { Ípróttir (bóklegar og } \\
\text { hreyfing) }\end{array}$ & 5 & 13 & 5 & 71 & 11 & (82) & 100 \\
\hline $\begin{array}{l}\text { Náttúruvísindagreinar } \\
\text { (eðlis-, efna-, líf-, jarð- og } \\
\text { umhverfisfræði) }\end{array}$ & 18 & 13 & 52 & 27 & 8 & (35) & 100 \\
\hline Sjónlistir og hönnun & 6 & 6 & 25 & 17 & 52 & (69) & 100 \\
\hline Stærðfræði & 14 & 10 & 66 & 13 & 11 & (24) & 100 \\
\hline Tölvunarfræði & 2 & 7 & 64 & 0 & 29 & (29) & 100 \\
\hline Dverfaglegt nám & 6 & 9 & 46 & 5 & 40 & $(45)$ & 100 \\
\hline
\end{tabular}

Mesta svigrúmið til frumkvæðis og sköpunar, pað er á 3. frumkvæðisprepi, var í sjónlistum og hönnun (52\% tímans), pverfaglegu námi (40\%) og íslensku (30\%). En ef 2. og 3. frumkvæðisprep eru tekin saman skáru prír námsgreinaflokkar sig úr, pað er ípróttir (82\%) og síðan sjónlistir (69\%) og íslenska (60\%), sem fyrr. Aftur á móti var um og yfir helmingur tíma greindur á 1. frumkvæðisprepi í erlendum tungumálum, félagsvísindagreinum, hugvísindagreinum, iðn- og starfsnámsgreinum, náttúruvísindagreinum og stærðfræði. 
Degar nemendur voru hins vegar spurðirí viðtölum um möguleika sína til frumkvæðisí mismunandi námsgreinum eða tækifæri til að láta sköpunargleđina njóta sín voru félagsvísindagreinar gjarnan nefndar. Lýst var kennara í félagsfræði: „Hann vill að við skrifum, pú veist, okkar, við megum ekki skrifa upp úr bókinni.“ I I öðrum skóla sagði nemandi: „Mér finnst miklu meiri umræða í ... félagsfræðiáföngunum. Dað er alltaf bara verið að tala saman og svona .... Mér finnst pað mjög fínt.“ Aftur á móti fengu náttúrufræðigreinar ekki sömu umsögn nemenda. Svar eins peirra var: „Mér finnst pað alls ekki pannig í náttúrufræðiáföngunum. ... Рað er bara eitthvað ákveðið rétt og pú verður bara að skila pví.“

Í stuttu máli bentu heildarniðurstöður rannsóknarinnar til pess að 1. frumkvæðisprepið tæki mestan tíma pegar á heildina væri litið. En talsverður munur kom fram milli kennsluhátta par sem hópverkefni gáfu mun umfangsmeiri tækifæri til frumkvæðis en einstaklingsverkefni og hópkennsla kennara. Allmikill munur var einnig milli skóla og námsgreina. Nemendur sáu ekki mikil tækifæri til frumkvæðis við úrlausn viðfangsefna í kennslustundum og virtist ekki vera umhugað um slíkt.

\section{Samantekt og umræða}

Markmið greinarinnar var að varpa ljósi á tækifæri framhaldsskólanemenda til frumkvæðis við úrlausn viðfangsefna í kennslustundum (sbr. skilgreiningar á mynd 1). Spurt var um umfang peirra (frumkvæðisprep og tímalengd) og birtingarmynd (í premur flokkum kennsluhátta), mun milli skóla, kennsluhátta og námsgreina og sjónarhorn nemenda. Markmiðið var sett fram í ljósi ákvæða í framhaldsskólalögum og námskrá og aldarlangrar umræðu fræðimanna um mikilvægi frumkvæðis nemenda og sköpunar í námi. Byggt var á vettvangslýsingum úr 130 kennslustundum og 17 hópviðtölum við nemendur (alls 56 nemendur). Niðurstöður benda til pess að kennsluhættir par sem kennarinn er í brennidepli og nemendur fást við að finna pekktar lausnir hafi enn yfirhöndina. Af peim má pví draga pá ályktun að umræður og stefnumörkun í heila öld um áherslur á frumkvæði og sköpun í námi og kennslu hafi í raun haft sáralítil áhrif.

\section{Skipting á prjú frumkvæðisprep - ásættanleg eða óásættanleg?}

Meginniðurstöður um umfang frumkvæðis nemenda eru pær að frumkvæði peirra og sköpun naut sín aðeins í um 19\% heildarkennslutímans, sem fylgst var með, pað er á 3. frumkvæðisprepi (mynd 2). Frumkvæði nemenda gat einnig notið sín að einhverju marki á 2. prepinu, eða í um $23 \%$ heildartímans, en óneitanlega var pá vart um sköpun að ræða, samkvæmt skilgreiningu hér framar. Fyrirlögð verkefni á 2. og 3. prepi samtals gáfu pví nemendum tækifæri til frumkvæðis 1 rétt innan við helming kennslutímans (42\%). Petta var hærra hlutfall en fram kom í rannsókn Gerðar G. Óskarsdóttur (2012) á fyrstu önn í níu framhaldsskólum í Reykjavík, par sem 10\% heildarkennslutíma sem fylgst var með voru á 3. prepi og 11\% á 2. prepi. Skýringin virðist ekki vera sú að frumkvæði nemenda aukist pegar líður á námsferilinn í framhaldsskóla (sbr. Árnýju Helgu Reynisdóttur og Ingólf Ásgeir Jóhannesson, 2013), par sem ekki kom fram munur á tækifærum til frumkvæðis í byrjendaáföngum og framhaldsáföngum í pessari athugun. Skýringin á pessum mun getur hugsanlega verið sú að próun hafi orðið í kennsluháttum framhaldsskólanna almennt frá gagnasöfnun í fyrri rannsókninni árið 2008 eða, sem virðist trúlegri skýring, að fyrst og fremst sé um mun á milli skóla almennt að ræða (sjá hér síðar).

Dess var vænst að heildarkennslutíminn skiptist nokkuð jafnt á frumkvæðisprepin prjú, en pess ber að geta að væntingar eru ekki hið sama og æskileg próun. Hér liggur sú eðlilega spurning í loftinu hve mikinn hluta skólatímans nemendur ættu að eiga tækifæri til að sýna frumkvæði. Svar við pví finnst hvorki í lögum né námskrá. Er kannski hæfilegt að leysa viðfangsefni á 3. frumkvæðisprepi í um fimmtungi tímans eða ætti frumkvæði nemenda að fá mun meiri tíma? Dótt höfundur hafi lagt upp með væntingar um nokkuð jafna skiptingu á milli priggja frumkvæðisprepa er alls ekki par með sagt að sú skipting sé ásættanleg, sumir vilja væntanlega setja markið hærra, jafnvel mun hærra. 


\section{Áherslur laga og fræða - munur milli skóla}

Niðurstöðurnar um tækifæri nemenda til frumkvæðis eru athyglisverðar í ljósi pess að ákvæði í lögum og námskrá fyrir framhaldsskóla lýsa áherslum á frumkvæði, sjálfstæði, sköpun og ráđrúm nemenda til áhrifa á námstilhögun, sem er í andstöðu við utanbókarlærdóm og mikla kennarastýringu (Lög um framhaldsskóla nr. 57/1988; Mennta- og menningarmálaráduneyti, 2011). En par má ætla að endurspeglist áherslur fjölda fræðimanna síðustu hundrað árin á náms- og kennsluhætti í takt við próun samfélagsins og nám við hæfi hvers og eins, reyndar undir ýmsum fræðiheitum. Umræddar hugmyndir, allt frá Dewey til hugmyndasmiða um einstaklingsmiðað nám, virðast pví ekki hafa náð að skjóta djúpum rótum í daglegu skólastarfi á framhaldsskólastigi hér á landi og hinni svokölluðu virku námskrá ekki tekist að fylgja eftir peirri áformuðu (Akker, 2003; Deci og Ryan, 1987; Fletcher, 2005; Hargreaves, 2006; Mitra, 2006; Rudduck, 2003; Tomlinson og McTighe, 2006). Sama á við um ítrekaða stefnumörkun sveitarfélaga og alpjóðlega framtíðarsýn undanfarna áratugi par sem lögð hefur verið áhersla á mikilvægi frumkvæðis og sköpunar í lífi og starfi (Brynjolfsson, 2017; European Commission; 2006, 2016; Reykjavíkurborg, 2018).

Tregða kerfisins til breytinga birtist í pessum niðurstöðum (Jón Torfi Jónasson, 2016). Í pví sambandi má rifja upp að snemma á síðustu öld gagnrýndi Dewey (1916/1966; 1938/2000) að við skipulag námsins væri gengið út frá pví að framtíðin yrði nánast eins og fortíðin og pví pyrfti skólinn ekki að breytast. Sú gagnrýni virðist enn eiga við. En hann varaði líka við pví að erfitt yrði að hverfa frá náms- og kennsluskipan „gamla skólans,“" - sem sjá má af niðurstöðunum.

Munur sem fram kom á milli skóla (mynd 3) er ein áhugaverðasta niðurstaða rannsóknarinnar par sem allir skólarnir starfa innan sambærilegs ramma laga, námskrár, námsefnis og kennaramenntunar. Hann bendir til pess að fyrrnefndar hugmyndir um tækifæri nemenda til frumkvæðis og sköpunar hafi náð inn í suma skólana, trúlega að frumkvæði starfsmanna (sbr. Fullan, 1998; Richardson, 1998). Í einum peirra var um 63\% heildartímans varið í úrlausn viðfangsefna á 2 . og 3. prepi - par sem nemendur nutu sín væntanlega sem sjálfstæðir og valdefldir einstaklingar (sbr. Deci og Ryan, 1987; Harvey og Burrows, 1992; Ingibjörgu V. Kaldalóns, 2015; Perry o.fl., 2006). Dreifing á prepin prjú var par í takt við væntingar um jafna dreifingu milli peirra. Aftur á móti unnu nemendur í öðrum skóla aðeins í um 25\% tímans samtals á 2. og 3. prepi, sem var langt undir pví sem búist var við. Dessi munur á skólum var meiri en fram kom í fyrrnefndri rannsókn frá 2012 (Gerður G. Óskarsdóttir, 2012). Í pessu sambandi má minna á að fræðimenn hafa sýnt fram á að tilraunir til breytinga standi gjarnan stutt (Tyack og Cuban, 1995). Dví verður fróðlegt að sjá hvernig tilraunum til að brjóta upp hefðbundna nálgun, í anda laga og fræða, í sumum skólanna reiðir af. Dað er efni í langtímarannsókn á náms- og kennsluháttum 1 framhaldsskólum. Dessar niðurstöður um tækifæri nemenda til frumkvæðis og mun á milli skóla vekja ekki síst hugleiðingar um val kennara á kennsluháttum, eða með öðrum orðum pær skorður eða ramma sem kennarar setja um starf nemenda og hve „stífur“ hann skuli vera.

\section{Val um kennsluhætti afdrifaríkt}

Birtingarmynd tækifæra nemenda til frumkvæðis var talsvert ólík milli kennsluháttaflokkanna priggja (tafla 1 og mynd 4). Val um kennsluhætti og framkvæmd peirra virðist pví skipta miklu máli hvað varðar möguleika nemenda til frumkvæðis við lausn viðfangsefna. Athygli vekur að samvinnuverkefni gáfu nemendum umfangsmestu tækifærin til frumkvæðis og pað í mun meiri mæli en einstaklingsverkefni. En samtals naut frumkvæði nemenda sín að einhverju marki í um $84 \%$ pess tíma sem unnið var saman í hópum (um 45\% á 3. prepi og 39\% á 2. prepi). Athyglisvert var að nemendur höfðu lítið frumkvæði að annars konar nálgun í nemendakynningum en kennararnir beittu, pótt pau væru jafnvel hvött af kennara til að ,vera frumleg og ... best [væri] að vera sem óvenjulegastur".

Aðeins í um fjórðungi tímans í einstaklingsverkefnum var svo að sjá að nemendur hefðu möguleika til frumkvæðis og sköpunar í náminu (á 3. frumkvæðisprepi). Ef til vill áttu nemendur frekar kost á að sýna frumkvæði og sköpun í einstaklingsverkefnum sem unnin voru utan skólatíma, en 
rannsóknin tók ekki til peirra.

Dær niðurstöður að kennsluhættir sem hér eru kallaðir hópkennsla væru umfangsmestir eru í samræmi við niðurstöður fyrri rannsókna á kennsluháttum í framhaldsskólum (sbr. Goodlad, 2004; Ingvar Sigurgeirsson o.fl., 2018; Svanhildi Kr. Sverrisdóttur, 2015). Detta má ef til vill skýra með pví að kennurum finnist peir ekki vera að kenna nema peir hafi sjálfir orðið og haldi stíft um stjórntaumana (Hafdís Ingvarsdóttir, 2004). Parna er kannski erfitt að finna meðalveg. Í pví sambandi má rifja upp sýn Deweys (1938/2000) sem sá alls ekki fyrir sér að kennarinn drægi sig algerlega í hlé heldur væri félagi, leiðtogi og leiðbeinandi í stað pess að vera einræðisherra í kennslustofunni. Einnig getur verið að yfirburði hópkennslu megi skýra með pví að framhaldsskólakennarar álíti að nemendur vilji láta mata sig og geri kröfur um að peim sé „kennt“ (Árný Helga Reynisdóttir og Ingólfur Ásgeir Jóhannesson, 2013). Engu að síður kom fram í nýrri rannsókn að hópur tungumálakennara taldi sig nota fjölbreyttar aðferðir sem gæfu nemendum tækifæri til að vera skapandi (Ásta Henriksen, 2018) og samræmt átak kennarahóps um að gefa nemendum meiri tækifæri til frumkvæðis leiddi til breytinga (Hjördís Porgeirsdóttir, 2018). Degar horft er til framtíðar má velta fyrir sér hvort rafrænir miðlar nútímans muni auka enn á frumkvæðisleysi nemenda eða verði uppspretta frumkvæðis og sköpunar í námi (Sólveig Jakobsdóttir, Torfi Hjartarson og Bergpóra Dórhallsdóttir, 2014).

Niðurstöður um takmarkaðan hlut skipulegra umræðna alls nemendahópsins (um 2\% heildarkennslutímans) má ef til vill skýra með fyrrnefndum hugmyndum kennara um mikilvægi pess að hafa stjórnina í sínum höndum og trú peirra á væntingar nemenda til mötunar. Velta má fyrir sér hvort lítil áhersla á skipulagðar umræður og skoðanaskipti milli nemenda í skólum sé að einhverju marki undirrót peirrar veiku umræðuhefðar sem virðist vera hér á landi á opinberum vettvangi (sbr. Frumvarp til laga um breytingu á lögum nr. 55/1991, um pingsköp Alpingis, 2011-2012). Pess ber að geta að umfjöllun um umræður náði ekki til umræðna nemenda í hópvinnu.

Munur var á möguleikum nemenda til frumkvæðis og sköpunar milli námsgreina. Mesta svigrúmið, eins og pað var skilgreint á 3. frumkvæðisprepinu, reyndist vera í sjónlistum og hönnun, sem ekki kom á óvart, og í pverfaglegu námi og íslensku (tafla 2).

Val um kennsluhætti virðist pannig áhrifaríkt hvað varðar tækifæri nemenda til frumkvæðis, en ekki var að sjá að nemendur væru með í ráđum um val á náms- og kennsluháttum.

\section{Frumkvæði ekki ofarlega í hugum nemenda}

Almennt virtist ráđrúm nemenda til frumkvæðis eða áhrifa í náminu ekki vera peim ofarlega í huga. Pegar nemendur voru spurðir um tækifæri sín til að hafa áhrif á námið, stýra pví, sýna frumkvæði eða láta hugmyndaauðgina njóta sín, gerðu pau líka frekar lítið úr möguleikunum. Viðmælendum, sem almennt voru á síðari hluta náms síns í framhaldsskóla, fannst spurningin varla eiga við eða eins og viðmælandi orðaði pað: „Ég geri bara pað sem mér er sagt.“ Detta er í samræmi við ályktanir um að nemendur reikni ekki með að geta haft eða eiga að hafa einhver áhrifí námi sínu (Valgerður S. Bjarnadóttir og Guðrún Geirsdóttir, 2018).

Nemendur töluðu reyndar vel um kennslustundir eða námsgreinar par sem pau töldu sig hafa eitthvað að segja. Nokkur áhugi virtist á að hafa meiri áhrif á framvindu námsins og vinnubrögð en venja væri, pótt ekki væri skýrt hvernig pað mætti gerast í framkvæmd, enda nemendur væntanlega ekki pjálfaðir í að láta í sér heyra (sbr. Selmu G. Selmudóttur, 2014). Einum fannst til dæmis nóg að ráđa framvindu á skilum verkefna. Annar vildi ekki láta segja sér svörin heldur skoða hlutina sjálfur. Sumir virtust preyttir á að vera frumkvæðislausir viðtakendur upplýsinga í kennslustundum, sem er í takt við rannsókn Maitles og Gilchrist (2005) par sem mikill meirihluti nemenda sagðist læra best pegar kennarinn reyndi að virkja pau til pátttöku. Jafnvel örlaði á að nemendur væru „,ðð stelast“ til að hafa frumkvæði, eins og mátti greina í svari nemanda sem talaði um að skrifa um eitthvað aðeins öðruvísi en ætlast væri til. 
Kröfur nemenda um svigrúm til frumkvæðis voru pannig ekki háværar og fremur lítilvæg atriði sem nefnd voru. Nemendum dettur ekki í hug að pau geti ráðið neinu og kannski eru kennarar sama sinnis, báðir hópar fastir í viðjum vanans. Detta er efni í aðra rannsókn, til dæmis meðal kennara um hugmyndir peirra og rök fyrir vali á kennsluháttum, en ekki síður tilefni til próunarverkefna í einstökum skólum.

\section{Lokaorð}

Von höfundar er að pessi athugun á frumkvæði nemenda við úrlausn viðfangsefna, sem byggðist á ákvæðum í lögum og námskrá, gefi tilefni til ígrundunar og umræðu um tækifæri nemenda til frumkvæðis og sköpunar innan mismunandi kennsluhátta og breytinga á peim. Hugmyndin um prjú frumkvæðisprep til að leggja mat á frumkvæði gæeti komið að gagni við undirbúning og framkvæm kennslu eða ekki síður próunarverkefna í einstökum skólum - sem talin hafa verið áhrifaríkari leið til breytinga en fyrirmæli ofan frá í lögum og námskrám ein og sér (Fullan, 1998; Richardson, 1998) eða viðleitni einstakra kennara (Slavin, 2008). En ekki síður væntir höfundur pess að niðurstöðurnar gefi ,framhaldsskóla í deiglu“ tilefni til vangaveltna um æskilega bróun í pessum efnum til að auðga skólastarfið og mæta pjóðfélagsbreytingum.

\section{Aftanmálsgrein}

[1] Megingagnasöfnun í rannsókninni Starfshættir í framhaldsskólum fór fram á tímabilinu október 2013 til nóvember 2014 í níu framhaldsskólum, auk pess sem rannsóknartækin voru forprófuð í tíunda skólanum. Gögnin eru vettvangslýsingar á 130 kennslustundum, yfir 60 afrituð viðtöl við nemendur (hópviðtöl), kennara og stjórnendur, ljósmyndir úr kennslustofum, kennsluáætlanir og önnur skrifleg gögn. Fimmtán manna hópur fræðafólks við Menntavísindaog Félagsvísindasvið Háskóla Íslands tók pátt í gagnasöfnuninni. Rannsóknin naut styrkja úr Rannsóknarsjódi Háskóla Íslands á árunum 2013-2015 og frá Norræna öndvegissetrinu Justice Through Education in the Nordic Countries, styrktu af NordForsk, 2013-2018. Úrvinnsla gagna fyrir pessa grein var styrkt af Hagpenki, félagi höfunda fræðirita og kennslugagna. Við pökkum sérstaklega framhaldsskólunum sem veittu aðgang að starfinu í rannsóknarskyni.

\section{Student initiative: Dropping in on classrooms in nine upper secondary schools}

This paper investigates student initiative, a competence highlighted in the laws (2008) and curriculum guide (2011) for upper secondary schools in Iceland. This emphasis is rooted in the educational discourse, for over a century, on the importance of students having a say in the education provided them, instead of being only inactive receivers of knowledge or followers of directions. In this discussion, the terms influence, activity, autonomy and empowerment are often cited, as well as initiative and creativity. The emphasis on initiative and creativity for the world of work and daily life is constantly reiterated nowadays, for example concerning technological development, innovation in the days of the fourth industrial revolution and key competences for the 21st century (see for example: European Commission, 2006, 2016). From this we could conclude that an important aim of education is to foster students' initiative. However, research indicates that teacher-centered methods are a firmly established approach in the classroom, thus providing limited space for student initiative and creativity.

Within the context of democracy in educational practices, grounded in Dewey's thinking, the aim of this paper is to cast light on upper secondary school student opportunities for initiative in their learning activities, including discussions, individual tasks and group work; more specifically, the scope and unfolding of these. 
The following definition was put forward as a norm for the analysis of data: Students exercise initiative in completing their assignments when they put their own stamp on their work, including the procedure and progress of learning, for example by expressing their ideas in writing or orally, or solving academic or vocational problems, individually or in groups, with no pre-existing solution.

This study is part of a larger research project: Teaching and Learning in Icelandic Upper Secondary Schools (students aged 16 to 19), aimed at obtaining a holistic view of the Icelandic upper secondary school (see Gerdur G. Oskarsdottir et al., 2018). The study was based on classroom observations of varied length in 130 academic and vocational classrooms (a total of 167 hours) in nine upper secondary schools, selected as a stratified sample from a total of 31. In addition, interviews with 17 student focus groups were analyzed, including 56 volunteers, 18 years or older. Data collection was in the hands of 15 researchers.

To analyze student initiative, a three step initiative-classification scale was applied (Gerdur G. Oskarsdottir, 2012). The first step indicates inactive receiving of knowledge, following directions or solving one-solution tasks. The second provides for some initiative and opportunity for choosing among several existing solutions. The last one signifies self-direction and the opportunity to exercise initiative and be creative in solving problems with no pre-existing solution, thus including the competence of creativity. The classification scale was applied to each of three categories of teaching approaches: whole class instruction, individual work, and group work. The proportion of time students worked on each step was estimated from the observation records, and their tasks on each step codified accordingly.

The findings indicate that around half of the classroom observation time, as measured in minutes, was classified as the first step on the initiative-classification scale, especially in the category of whole class instruction ( $75 \%$ of that category). Around a fourth of the observation time was assigned to the second step, largely distributed between individual work and group work. Approximately $20 \%$ of the time was codified as the third step, with creativity in action, especially in group work (close to $50 \%$ in that category). The interviews reflected these findings. The students did not see themselves as exercising a significant level of initiative, in some cases, not even considering it as an option.

These findings, including the low proportion of time analyzed for the third step, indicate the significance of Dewey's thinking for 21st century education. Realization of his ideas has a long way to go. The purpose of the study was, indeed, to create a norm that teachers and school leaders could apply in their reflection on teaching practices and school development.

Key words: Initiative, creativity, teaching and learning, initiative-classification scale, upper secondary school.

\section{Um höfundinn}

Gerður G. Óskarsdóttir (gerdurgo@simnet.is) lauk doktorsprófi í menntunarfræði frá Kaliforníuháskóla í Berkeley 1994, meistaraprófi í námsráđgjöf frá Bostonháskóla 1981, BA-prófi frá Háskóla Íslands 1969 og kennaraprófi frá Kennaraskóla Íslands 1964. Gerður hefur starfað sem kennari og stjórnandi á grunn-, framhalds- og háskólastigi, ráðunautur menntamálaráðherra og yfirmaður leik- og grunnskóla Reykjavíkurborgar. Rannsóknir hennar hafa einkum snúist um brotthvarf, tengsl menntunar og starfs, náms- og starfsráđgjöf, kennsluhætti og skil skólastiga. 


\section{About the author}

Gerður G. Óskarsdóttir (gerdurgo@simnet.is) completed a PhD in educational administration from the University of California at Berkeley in 1994, a MEd in school counseling from Boston University in 1981, a BA from the University of Iceland 1969, and diplomas leading to teaching certificates in 1971 and 1964. Gerður has served as teacher and administrator at primary, secondary and university levels and has been a consultant to the minister of education and superintendent of schools in the Reykjavik district. Her research has focused on drop outs, school-to-work relations, school counseling, teaching and learning, and educational transitions.

\section{Heimildir}

Akker, J. van den. (2003). Curriculum perspectives: An introduction. Í J. van den Akker, W. Kuiper og U. Hameyer (ritstjórar), Curriculum landscape and trends (bls. 1-10). Dordrecht: Kluwer Academic Publishers.

Anna Kristín Sigurðardóttir. (2007). Dróun einstaklingsmiðaðs náms í grunnskólum Reykjavíkur. Netla - Veftímarit um uppeldi og menntun. Sótt af http://netla.khi.is/greinar/2007/012/index.htm

Arnot, M. og Reay, D. (2007). A sociology of pedagogic voice: Power, inequality and pupil consultation. Discourse: Studies in the Cultural Politics of Education, 28(3), 311-325. doi:10.1080/01596300701458814

Árný Helga Reynisdóttir og Ingólfur Ásgeir Jóhannesson. (2013). Fleiri vindar blása.Viðhorf reyndra framhaldsskólakennara til breytinga í skólastarfi 1986-2012. Netla - Veftímarit um uppeldi og menntun. Sótt af http://netla.hi.is/greinar/2013/ ryn/006.pdf

Ásta Henriksen. (2018) Sköpun skiptir sköpum:Viðhorf tungumálakennara til skapandi kennsluhátta. Netla - Veftímarit um uppeldi og menntun. Sérrit 2018 - Framhaldsskólinn í brennidepli. Sótt af http://netla.hi.is/serrit/2018/framhaldskolinn_brennidepli/08.pdf

Bowkett, S. (2005). 100+ ideas for teaching creativity. London: Continuum.

Brynjolfsson, E. (2017, 4. janúar). Technology is changing the way we live, learn and work. How can leaders make sure we all prosper? Sótt af https://www.weforum.org/agenda/2017/01/technology-is-changing-the-way-we-live-learnand-work-how-can-leaders-make-sure-we-all-prosper/

Carver, R. L. og Enfield, R. P. (2006). John Dewey's philosophy of education is alive and well. Education and Culture, 22(1), 55-67.

Charles, C. M. (1982). Litla Piaget kverið (Jóhann S. Hannesson pýddi, 2. útgáfa). Reykjavík: Námsgagnastofnun (frumútgáfa 1974).

Deci, E. L. og Ryan, R. M. (1987). The support of autonomy and the control of behavior. Journal of Personality and Social Psychology, 53(6), 1024-1037.

Dewey, J. (1966). Democracy and education. An introduction to the philosophy of education. New York:The Free Press (frumútgáfa 1916).

Dewey,J. (2000). Reynsla og menntun (Gunnar Ragnarsson pýddi). Reykjavík: Rannsóknarstofnun Kennaraháskóla Íslands (frumútgáfa 1938).

European Commission. (2006). Recommendation of the European parliament and of the Council of 18 December 2006 on key competences for lifelong learning. Official Journal of the European Union 49(L 394), 10-18. Sótt af http://www. cedefop.europa.eu/en/news-and-press/news/recommendation-18-december-2006-key-competences-lifelong-learning

European Commission. (2016). EntreComp: The entrepreneurship competence framework. Sótt af https://ec.europa.eu/jrc/ en/publication/eur-scientific-and-technical-research-reports/entrecomp-entrepreneurship-competence-framework

Fletcher,A. (2005). Meaningful student involvement: Guide to students as partners in school change. Sótt af http://www.soundout.org/MSIGuide.pdf

Frumvarp til laga um breytingu á lögum nr. 55/1991, um pingsköp Alpingis. Dingskjal 27, 2011-2012. Sótt af https:// www.althingi.is/altext/140/s/0027.html

Fullan, M. (1998). The meaning of educational change: A quarter of a century of learning. Í A. Hargreaves, A. Lieberman, M. Fullan og D. Hopkins (ritstjórar), International handbook of educational change (bls. 214-228). Dordrecht: Kluwer.

Gerður G. Óskarsdóttir. (2003). Skólastarf á nýrri öld. Reykjavík: Fræðslumiðstöð Reykjavíkur.

Gerður G. Óskarsdóttir. (2012). Skil skólastiga. Frá leikskóla til grunnskóla og grunnskóla til framhaldsskóla. Reykjavík: Háskólaútgáfan og Skóla- og frístundasvið Reykjavíkurborgar. 
Gerður G. Óskarsdóttir, Amalía Björnsdóttir, Anna Kristín Sigurðardóttir, Börkur Hansen, Ingvar Sigurgeirsson, Kristín Jónsdóttir, . . Sólveig Jakobsdóttir. (2014). XII. Starfshættir í grunnskólum. Meginniðurstöður og umræða. Í Gerður G. Óskarsdóttir (ritstjóri), Starfshœettir í grunnskólum við upphaf 21. aldar (bls. 323-347). Reykjavík: Háskólaútgáfan.

Gerður G. Óskarsdóttir og rannsóknarhópur um starfshætti í framhaldsskólum. (2018). Starfshættir í framhaldsskólum: Aðdragandi og framkvæmd rannsóknar 2012-2018. Netla - Veftímarit um uppeldi og menntun. Sérrit 2018 - Framhaldsskólinn í brennidepli. Sótt af http://netla.hi.is/serrit/2018/framhaldskolinn_brennidepli/01.pdf

Goodlad, J. I. (2004). A place called school. New York: McGrawHill.

Guðmundur Finnbogason. (1994). Lýðmenntun. Hugleiðingar og tillögur. Reykjavík: Rannsóknarstofnun Kennaraháskóla Íslands í samstarfi við Félagsvísindastofnun Háskóla Íslands og Sagnfræðistofnun Háskóla Íslands (frumútgáfa 1903).

Hafdís Ingvarsdóttir. (2004). „... ef pað er eitthvað sem peim pykir áhugavert.“ Enskukennsla við upphaf 21. aldar. Í Úlfar Hauksson (ritstjóri), Rannsóknir í félagsvísindum V (bls. 471-481). Reykjavík: Háskólaútgáfan.

Hafdís Ingvarsdóttir. (2018). Kennsluhættir speglaðir í ljósi sjálfræðis:Virðing, ábyrgð og traust. Netla - Veftímarit um uppeldi og menntun. Sérrit 2018 - Framhaldsskólinn í brennidepli. Sótt af http://netla.hi.is/serrit/2018/framhaldskolinn_brennidepli/03.pdf

Hafpór Guðjónsson. (2010). Að vitsmunir barnanna proskist á náminu ... Netla-Veftímarit um uppeldi og menntun. Sótt af http://netla.hi.is/greinar/2010/010/index.htm

Hargreaves, D. H. (2006). A new shape for schooling? London: Specialist Schools and Academic Trust.

Harvey, L. og Burrows, A. (1992). Empowering students. The New Academic, 1(3), 1-3.

Hjördís Dorgeirsdóttir. (2018). The Change Room promotes teachers' agency to change their practice. Educational Action Research, febrúar 2018. doi:10.1080/09650792.2018.1436080

Ingibjörg V. Kaldalóns. (2015). Stuðningur við sjálfreði nemenda í íslenskum grunnskólum (óútgefin doktorsritgerð). Háskóli Íslands, Reykjavík.

Ingvar Sigurgeirsson. (2013). Litróf kennsluađferðanna. Handbók fyrir kennara og kennaraefni. Reykjavík: Iðnú.

Ingvar Sigurgeirsson, Amalía Björnsdóttir, Gunnhildur Óskarsdóttir og Kristín Jónsdóttir. (2014).VI. Kennsluhættir. Í Gerður G. Óskarsdóttir (ritstjóri), Starfshœettir í grunnskólum við upphaf 21. aldar (bls. 113-158). Reykjavík: Háskólaútgáfan.

Ingvar Sigurgeirsson, Elsa Eiríksdóttir og Ingólfur Ásgeir Jóhannesson. (2018). Kennsluaðferðir í 130 kennslustundum í framhaldsskólum. Netla - Veftímarit um uppeldi og menntun. Sérrit 2018 - Framhaldsskólinn í brennidepli. Sótt af http:// netla.hi.is/serrit/2018/framhaldskolinn_brennidepli/09.pdf

Jóhanna Einarsdóttir og Ólafur Páll Jónsson (ritstjórar). (2010). John Dewey í hugsun og verki. Menntun, reynsla og lýdreæði. Reykjavík: RannUng, Heimspekistofnun Háskóla Íslands og Háskólaútgáfan.

Jón Torfi Jónasson. (2016). Educational change inertia and potential futures. Why is it difficult to change the content of education? European Journal of Futures Research, 4(1), 1-14. doi:10.1007/s40309-016-0087-z

Key, E. (1911). Barnets århundrade: Studie. Stokkhólmi: Bonnier (frumútgáfa 1902).

Kristín Indriðadóttir. (1995). Hugmyndir Steingríms Arasonar um kennslu og skólastarf. Uppruni og afdrif. Uppeldi og menntun, 4, 9-33.

Lög um framhaldsskóla nr. 57/1988.

Lög um framhaldsskóla nr. 92/2008.

Maitles, H. og Gilchrist, I. (2005). 'We're citizens now'! the development of positive values through a democratic approach to learning. Journal of Critical Education Policy Studies, 3(1) 85-111.

Mennta- og menningarmálaráđuneyti. (2011). Aðalnámskrá framhaldsskóla: Almennur hluti 2011. Reykjavík: Höfundur.

Mitra, D. L. (2006). Student voice from the inside and outside: The positioning of challengers. International Journal of Leadership in Education, 9(4), 315-328.

OECD/CERI. (2008). 21st century skills: How can you prepare students for the new global economy? Sótt af https://www. oecd.org/site/educeri21st/40756908.pdf

Orðabanki Íslenskrar málstöðvar (e.d.). Sköpun. Sótt af http://www.ordabanki.hi.is/wordbank/terminfo?idTer$\mathrm{m}=774068 \&$ FirstResult $=0$

Ólafur Páll Jónsson. (2010). Hugsun, reynsla og lýðræði. Í Jóhanna Einarsdóttir og Ólafur Páll Jónsson (ritstjórar), John Dewey i hugsun og verki. Menntun, reynsla og lýdraði (bls. 13-41). Reykjavík: RannUng, Heimspekistofnun Háskóla Íslands og Háskólaútgáfan.

Patall, E. A., Cooper, H. og Robinson, J. C. (2008). The effects of choice on intrinsic motivation and related outcomes: A meta-analysis of research findings. Psychological Bulletin, 134(2), 270-300.

Perry, N. E., Phillips, L. og Hutchinson, L. (2006). Mentoring student teachers to support self-regulated learning. The Elementary School Journal 106(3), 237-254. 
Pring, R. (2017). Educational philosophy of John Dewey and its relevance to current dilemmas in education. Education in the North, 24(1), bls. 3-15.

Reykjavíkurborg. (2018). Menntastefna Reykjavíkurborgar til 2030 „Látum draumana retast“. Sótt af https://reykjavik.is/ sites/default/files/menntastefna_reykjavikur_til_2030.pdf

Richardson,V. (1998) How teachers change. What will lead to change that most benefits student learning? Sótt af http:// www.ncsall.net/index.html@id=771\&pid=395.html

Rudduck, J. (2003). Pupil voice and citizenship education: A report for the QCA citizenship and PSHE team. Cambridge: University of Cambridge.

Selma G. Selmudóttir. (2014). Gódir hlutir gerast hagt: ferðasaga nýs kennara sem vill auka sjálfreði nemenda sinna (óútgefin MA-ritgerð). Háskóli Íslands, Reykjavík. Sótt af http://hdl.handle.net/1946/19697

Slavin, R. E. (2008). Cooperative learning, success for all, and evidence-based reform in education. Éducation $\&$ Didactique, 2(2), 149-157.

Sólveig Jakobsdóttir, Torfi Hjartarson og Bergpóra Pórhallsdóttir. (2014). XI. Upplýsingatækni í skólastarfi. Í Gerður G. Óskarsdóttir (ritstjóri), Starfshattir í grunnskólum við upphaf 21. aldar (bls. 277-319). Reykjavík: Háskólaútgáfan.

Steinunn Gestsdóttir. (2012). Sjálfstjórnun barna og ungmenna: Staða pekkingar og pýðing fyrir skólastarf. Uppeldi og menntun 21(2), 19-41.

Svanborg R. Jónsdóttir, Meyvant Pórólfsson, Jóhanna Karlsdóttir og Gunnar E. Finnbogason. (2014). Að uppfæra Ísland: Sýn stjórnenda íslenskra framhaldsskóla á nýsköpunar- og frumkvöðlamennt og framkvæmd námssviðsins í námskrárfræðilegu ljósi. Netla - Veftímarit um uppeldi og menntun. Sótt af http://netla.hi.is/greinar/2014/ryn/011.pdf

Svanhildur Kr. Sverrisdóttir. (2015). Ef að er gád: Afdrif aðalnámskrár i íslensku á unglingastigi grunnskóla og í framhaldsskóla (óútgefin doktorsritgerð). Háskóli Íslands, Reykjavík.

Tomlinson, C. A. og McTighe, J. (2006). Integrating differentiated instruction and understanding by design: Connecting content and kids. Alexandria,VA:Association for Supervision and Curriculum Development.

Trilling, B. og Fadel, C. (2009). 21st century skills. Learning for life in our times. San Francisco: Jossey-Bass.

Tyack, D. og Cuban, L. (1995). Tinkering toward utopia: A century of public school reform. Cambridge, MA: Harvard University Press.

Valgerður S. Bjarnadóttir og Guðrún Geirsdóttir. (2018). 'You know, nothing changes'. Students' experiences in influencing pedagogic practices in various upper secondary schools in Iceland. Pedagogy, Culture \& Society, 26(4), 631-646. doi.org/10.1080/14681366.2018.1439995

Gerður G. Óskarsdóttir. (2018).

Frumkvæði nemenda: Innlit í kennslustundir níu framhaldsskóla.

Netla - veftímarit um uppeldi og menntun. Sérrit 2018 - Framhaldsskólinn í brennidepli.

Menntavísindasvið Háskóla Íslands.

Sótt af http://netla.hi.is/serrit/2018/framhaldskolinn_brennidepli/06.pdf

DOI: https://doi.org/10.24270/serritnetla.2019.6 